\title{
Plants and Natural Products with Activity against Various Types of Coronaviruses: A Review with Focus on SARS-CoV-2
}

\author{
Susana A. Llivisaca-Contreras ${ }^{1}{ }^{1}$, Jaime Naranjo-Morán ${ }^{2}{ }^{\oplus}$, Andrea Pino-Acosta ${ }^{3}$, Luc Pieters ${ }^{4}{ }^{\oplus}$, \\ Wim Vanden Berghe ${ }^{4,5}{ }^{-}$, Patricia Manzano ${ }^{2,6}$, Jeffrey Vargas-Pérez ${ }^{2}$, Fabian León-Tamariz ${ }^{5,7, *}$ \\ and Juan M. Cevallos-Cevallos $2,5,6, * \mathbb{B}$
}

Citation: Llivisaca-Contreras, S.A. Naranjo-Morán, J.; Pino-Acosta, A.; Pieters, L.; Vanden Berghe, W.; Manzano, P.; Vargas-Pérez, J.; León-Tamariz, F.; Cevallos-Cevallos, J.M. Plants and Natural Products with Activity against Various Types of Coronaviruses: A Review with Focus on SARS-CoV-2. Molecules 2021, 26, 4099. https://doi.org/10.3390/ molecules26134099

Academic Editor: Raphaël E. Duval

Received: 22 May 2021

Accepted: 15 June 2021

Published: 5 July 2021

Publisher's Note: MDPI stays neutral with regard to jurisdictional claims in published maps and institutional affiliations.

Copyright: (c) 2021 by the authors. Licensee MDPI, Basel, Switzerland. This article is an open access article distributed under the terms and conditions of the Creative Commons Attribution (CC BY) license (https:// creativecommons.org/licenses/by/ $4.0 /)$.
1 Escuela Superior Politécnica del Litoral, ESPOL, Centro de Agua y Desarrollo Sustentable, CADS, Campus Gustavo Galindo Km. 30.5 vía Perimetral, Guayaquil EC090112, Ecuador; susalliv@espol.edu.ec

2 Escuela Superior Politécnica del Litoral, ESPOL, Centro de Investigaciones Biotecnológicas del Ecuador, CIBE, Campus Gustavo Galindo Km. 30.5 vía Perimetral, Guayaquil EC090112, Ecuador; jaianara@espol.edu.ec (J.N.-M.); pmanzano@espol.edu.ec (P.M.); jefdavar@espol.edu.ec (J.V.-P.)

3 Escuela Superior Politécnica del Litoral, ESPOL, Facultad de Arte, Diseño y Comunicación Audiovisual, FADCOM, Bosque Protector La Prosperina, Campus Gustavo Galindo Km. 30.5 vía Perimetral, Guayaquil EC090112, Ecuador; ypino@espol.edu.ec

4 Natural Products \& Food Research and Analysis (NatuRA), Department of Pharmaceutical Sciences, University of Antwerp, 2610 Antwerp, Belgium; luc.pieters@uantwerpen.be (L.P.); wim.vandenberghe@uantwerpen.be (W.V.B.)

5 Red Universitaria Para la Investigación y Posgrados Vlir Network, Km. 30.5 vía Perimetral, Edificio Principal, Vicerrectorado Académico (2 Piso), Guayaquil EC090112, Ecuador

6 Escuela Superior Politécnica del Litoral, ESPOL, Facultad de Ciencias de la Vida, FCV, Centro de Investigaciones Biotecnológicas del Ecuador, CIBE, Campus Gustavo Galindo Km. 30.5 vía Perimetral, Guayaquil EC090608, Ecuador

7 Grupo de Plantas Medicinales y Productos Naturales, Departamento de Biociencias, Facultad de Ciencias Químicas, Universidad de Cuenca, Av. 12 de Abril, Cuenca EC010107, Ecuador

* Correspondence: fabian.leont@ucuenca.edu.ec (F.L.-T.); jmceva@espol.edu.ec (J.M.C.-C.); Tel.: +593-7-4051000 (ext. 2400) (F.L.-T.); +593-42269610 (J.M.C.-C.)

Abstract: COVID-19 is a pandemic disease caused by the SARS-CoV-2 virus, which is potentially fatal for vulnerable individuals. Disease management represents a challenge for many countries, given the shortage of medicines and hospital resources. The objective of this work was to review the medicinal plants, foods and natural products showing scientific evidence for host protection against various types of coronaviruses, with a focus on SARS-CoV-2. Natural products that mitigate the symptoms caused by various coronaviruses are also presented. Particular attention was placed on natural products that stabilize the Renin-Angiotensin-Aldosterone System (RAAS), which has been associated with the entry of the SARS-CoV-2 into human cells.

Keywords: middle east respiratory syndrome (MERS); severe acute respiratory syndrome coronavirus (SARS-CoV); renin-angiotensin-aldosterone system (RAAS); angiotensin-converting enzyme inhibitors (ACEi); coronavirus disease of 2019 (COVID-19); medicinal plants; antiviral; viral entry inhibitors; biomolecules

\section{Introduction}

The Coronavirus Disease 2019 (COVID-19), caused by the Severe Acute Respiratory Syndrome Coronavirus 2 (SARS-CoV-2), was declared a pandemic on 11 March 2020 [1] and is probably the biggest challenge for public health systems in most countries given the limited knowledge about effective treatments [2].

The SARS-CoV-2 belongs to the Coronaviridae family and the Coronavirinae subfamily which has been divided into four genera: $\alpha$-coronavirus, $\beta$-coronavirus, $\gamma$-coronavirus and $\delta$-coronavirus [3]. The Human Coronavirus species HCoV (OC43, 229E, NL63 and HKU1), as well as those associated with Severe Acute Respiratory Syndrome (SARS), Middle East 
Respiratory Syndrome (MERS), and SARS-CoV-2, can cause respiratory tract infection but others such as the species 229E, OC43, HKU1, and NL63 usually cause the common cold [3]. Genetic characterization has shown that SARS-CoV-2 shares almost $80 \%$ of the SARS$\mathrm{CoV}$ [4] and $96.2 \%$ of the bat $\beta$-coronaviruses lineage B [1] genomes. The SARS-CoV-2 belongs to the $\beta$-coronavirus group and causes milder symptoms than SARS and MERS but the transmission between people is much faster with an R0 (Basic Reproduction Number) of 3.28 [5] compared to the R0 values around 0.9 for MERS-CoV [2]. The mortality rate for SARS-CoV-2 is $3.4 \%$ compared to $9.6 \%$ and $35 \%$ for SARS-CoV and MERS respectively [6]. The incubation period for SARS is 2 to 10 days, while that of SARS-CoV-2 is 1 to 14 days (Table 1) [4]. Additionally, several studies reported that SARS-CoV-2 and SARS-CoV use the Angiotensin-Converting Enzyme 2 (ACE2) as a receptor to enter target cells, while MERS-CoV uses dipeptidyl peptidase 4 (DPP4) for the same purpose (Table 1) [2]. The alveolar lung and small intestine are potential targets for SARS-CoV-2 due to the high expression of ACE2 [1].

Table 1. Pathogenetic and epidemiological characteristics of SARS-CoV-2, SARS-CoV and MERS-CoV.

\begin{tabular}{|c|c|c|c|c|c|}
\hline Species & Receptor & Incubation Period & RO & Case Fatality Rate & References \\
\hline SARS-CoV-2 & ACE2 & 1 to 14 days & 3.28 & 3.4 & {$[3,5,7]$} \\
\hline SARS-CoV & ACE2 & \multirow{2}{*}{2 to 10 days } & $1.7-1.9$ & 9.6 & {$[4,8]$} \\
\hline MERS-CoV & DPP4 & & 0.9 & 35 & [2] \\
\hline
\end{tabular}

SARS-CoV-2 mainly affects the middle-aged and elderly, as well as people with underlying diseases such as hypertension, diabetes, obesity or with heart and kidney problems, but shows low severity in children [7] although the disease transmission in this age group is still unknown [2] and the infection rates in children are increasing with the emergence of new SARS-CoV-2 variants [9].

Home isolation and quarantine have been applied in most countries to reduce the spread of the disease. However, this measure is also leading to economic, social and political deterioration in the affected countries. Consequently, the cases of anxiety and depression due to confinement as well as the number of deaths due to these causes have increased [10]. The enormous worldwide effort to develop vaccines against COVID-19 is recognized well-known as at least 19 vaccines have entered clinical trials and some vaccines already being applied to people in several countries [11]. However, the rushed development of a vaccine is usually accompanied by numerous challenges including potentially severe side effects and the possible loss of disease protection shortly after vaccination [12]. Moreover, the rise of new virus variants can affect the effectiveness of current treatments.

Similarly, other large-scale trials are in progress for the evaluation of possible therapies, including the World Health Organization (WHO) Solidarity Trial [11]. Pharmaceutical products undergoing clinical trials as potential treatments for COVID-19 include the antiviral nucleotide analog remdesivir, systemic interferons, and monoclonal antibodies [11]. Moreover, the antiparasitic drug ivermectin has been repurposed as a potential antiviral against SARS-CoV-2 and some drugs such as hydroxychloroquine that initially seemed promising have already been discarded by conflicting results through small-scale studies [12].

The accelerated search for a cure involves questions of a bioethical nature which prompts a reflection on the Declaration of Helsinki [2013] as well as the non-maleficence and beneficence principles to enable the use of untested procedures in clinical trials under emergency conditions [13]. It is necessary to implement a sustainable program to improve the health of citizens while a cure for SARS-CoV-2 is developed. Medicinal plants and natural products have the potential for enhancing people's health and boost the immune system [14]. Plants generally contain a combination of active ingredients or phytochemicals with different properties. Herbal medicinal formulations have been effective in treating emerging and reemerging viral diseases affecting diverse human and animal popula- 
tions [14]. Plant extracts have shown specific antiviral properties in experimental animal models, which have prompted the formulation of natural products for the treatment of viral diseases [15]. Similarly, the bioactive compounds of medicinal plants can act as immunomodulators and can be combined with other therapies against viral diseases [16].

Natural products can help researchers design safe and easily accessible medical treatments [17]. For instance, plants from traditional Chinese medicine (TCM) such as Scutellaria baicalensis contain various antiviral compounds, including inhibitors of viral replication [18] and phytochemicals with anti-SARS-CoV-2 potential (Table 2). Furthermore, 125 Chinese herbs were found to contain at least 2 of 13 compounds (betulinic acid, coumaroyltyramine, cryptotanshinone, desmethoxyreserpine, dihomo- $\gamma$-linolenic acid, dihydrotanshinone I, kaempferol, lignan, moupinamide, N-cis-feruloyltyramine, quercetin, sugiol, tanshinone IIa) that can inhibit the 3C-Like protease (3CLpro) and Papain-Like protease (PLpro) as well as block the entry, replication and binding of the SARS-CoV-2 Spike protein (S protein) [19]. Similarly, a protective effect against the $229 \mathrm{E}$ coronavirus was observed in respiratory cell cultures pre-treated with $50 \mu \mathrm{g} / \mathrm{mL}$ Echinacea (Table 2) [20]. In addition, the highly pathogenic SARS and MERS coronaviruses were also inactivated in vitro $\left(\mathrm{IC}_{50} 3.2 \mathrm{ug} / \mathrm{mL}\right)$ using the same plant. Other species such as grapefruit (Citrus $\times$ paradisi) have also been used to combat several respiratory infections [21].

Table 2. Medicinal plants and natural products with inhibitory activity against various types of coronaviruses.

\begin{tabular}{|c|c|c|c|}
\hline Scientific/Common Name & Active Principle & Virus/ Antiviral Activity & Reference \\
\hline $\begin{array}{l}\text { Aesculus hippocastanum } \mathrm{CN} \text { : } \\
\text { Horse-chestnut }\end{array}$ & Aescin $(\mathrm{k})$ & SARS-CoV/Inhibits viral replication & [22] \\
\hline $\begin{array}{l}\text { Allium ampeloprasum Var. } \\
\text { porrum J. Gay } \\
\text { CN: Leek }\end{array}$ & $\begin{array}{l}\text { Mannose-binding specific } \\
\text { lectin (b) }\end{array}$ & $\begin{array}{l}\text { SARS-CoV/Ability to bind to the glycosylated } \\
\text { molecules found on the surface of viruses, } \\
\text { including the spike glycoprotein }\end{array}$ & $\begin{array}{l}{[23]} \\
{[24]}\end{array}$ \\
\hline $\begin{array}{l}\text { Allium cepa L. } \\
\text { CN: Onion }\end{array}$ & $\begin{array}{l}\text { Flavonols: quercetin, } \\
\text { quercetinglycosides } \\
\text { (isoquercitrin, quercitrin and } \\
\text { rutin) (c) and kaempferol (j) }\end{array}$ & $\begin{array}{l}\text { SARS-CoV2/Interfere with various stages of the } \\
\text { coronavirus entry and replication cycle such as } \\
\text { PLpro, 3CLpro, and NTPase/helicase; Inhibits } \\
\text { ACE by competing with the substrate, } \\
\text { N-[3-(2-furyl) } \\
\text { acryloyl]-L-phenylalanylglycylglycine }\end{array}$ & $\begin{array}{l}{[25]} \\
{[26]}\end{array}$ \\
\hline $\begin{array}{l}\text { Brassica oleracea L. } \\
\text { CN: Broccoli }\end{array}$ & Glucosinolate type sinigrin (z) & SARS-CoV/blocks the cleavage process of 3CLpro & $\begin{array}{l}{[27]} \\
{[28]}\end{array}$ \\
\hline $\begin{array}{l}\text { Bupleurum spp. } \\
\text { CN: Bupleurum }\end{array}$ & $\begin{array}{l}\text { Oleanane-type } \\
\text { saikosaponins (aj) }\end{array}$ & $\begin{array}{l}\text { SARS-CoV/Inhibit human coronavirus entry into } \\
\text { cells, general replication, and specific 3CLpro } \\
\text { mediated replication }\end{array}$ & [29] \\
\hline $\begin{array}{l}\text { Cassia tora } \mathrm{L} . \\
\mathrm{CN} \text { : }\end{array}$ & $\begin{array}{l}\text { Anthraquinone derived } \\
\text { emodin (a) }\end{array}$ & $\begin{array}{l}\text { Inhibitory activities on } \\
\text { angiotensin-converting enzyme. }\end{array}$ & [28] \\
\hline $\begin{array}{l}\text { Cinnamomum verum J. Presl } \\
\mathrm{CN} \text { : Cinnamon (cortex) }\end{array}$ & Butanol (v), procyanidins (ai) & $\begin{array}{l}\text { SARS-CoV/Possibly blocks the entry of cells } \\
\text { through endocytosis }\end{array}$ & $\begin{array}{l}{[30]} \\
{[31]} \\
{[32]}\end{array}$ \\
\hline $\begin{array}{l}\text { Curcuma spp. } \\
\text { CN: Turmeric }\end{array}$ & $\begin{array}{l}\text { Curcumin (y), } \\
\text { Eugenol (an) }\end{array}$ & $\begin{array}{l}\text { SARS-CoV/Inhibits 3CLpro (y); Good binding } \\
\text { affinity with Mpro and S protein (an) }\end{array}$ & $\begin{array}{l}{[33]} \\
{[34]}\end{array}$ \\
\hline $\begin{array}{l}\text { Citrus spp. } \\
\text { CN: Three main species in the } \\
\text { country: Citrus maxima } \\
\text { (Rumph. ex Burm.) Merr; } \\
\text { Citrus medica L.; Citrus } \\
\text { reticulata Blanco. }\end{array}$ & $\begin{array}{l}\text { Hesperetin (f) and } \\
\text { naringenin (e) }\end{array}$ & $\begin{array}{l}\text { SARS-CoV-2/(f) Inhibits ACE2 and inhibit the } \\
\text { entry of virus into cells host by binding to S } \\
\text { protein, helicase, and protease sites on the } \\
\text { ACE receptor } \\
\text { HCoV229E/(e) Partial inhibition of } 229 \mathrm{E} \\
\text { replication in cells silenced for TPC2 by siRNA }\end{array}$ & $\begin{array}{l}{[35]} \\
{[36]}\end{array}$ \\
\hline
\end{tabular}


Table 2. Cont.

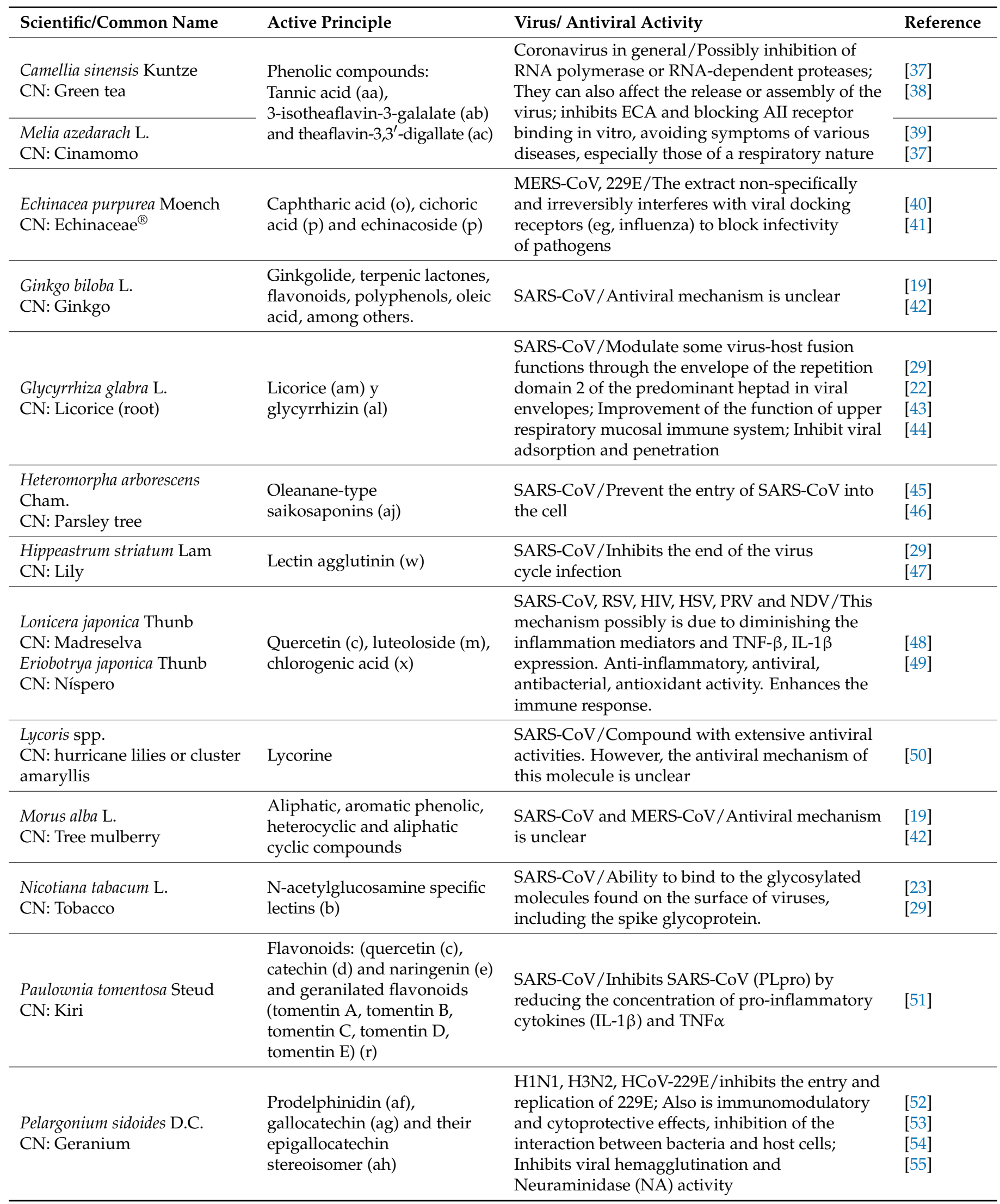


Table 2. Cont.

\begin{tabular}{|c|c|c|c|}
\hline Scientific/Common Name & Active Principle & Virus/ Antiviral Activity & Reference \\
\hline $\begin{array}{l}\text { Psidium guajava } \\
\text { CN: Guava }\end{array}$ & Eugenol (an) & $\begin{array}{l}\text { SARS-CoV/Good binding affinity with Mpro and } \\
\text { S protein }\end{array}$ & $\begin{array}{l}{[34]} \\
{[21]}\end{array}$ \\
\hline $\begin{array}{l}\text { Scutellaria baicalensis Georgi. } \\
\text { CN: Skullcap }\end{array}$ & Baicalin (g) and scutellarein (l) & $\begin{array}{l}\text { SARS-CoV/Inhibits nsP13 in vitro by affecting } \\
\text { ATPase activity }\end{array}$ & $\begin{array}{l}{[56]} \\
{[57]} \\
{[46]}\end{array}$ \\
\hline
\end{tabular}

Thuja orientalis L.

$\mathrm{CN}$ : Tree of life

Laurus nobilis L.

CN: Laurel

Salvia officinalis L.

$\mathrm{CN}$ : Sage

\begin{tabular}{|c|c|}
\hline $\begin{array}{l}\text { Urtica dioica L. } \\
\text { CN: Nettle }\end{array}$ & Lectin agglutinin $(\mathrm{w})$ \\
\hline $\begin{array}{l}\text { Polygonum cuspidatum L. } \\
\text { CN: Japanese knotty grass }\end{array}$ & $\begin{array}{l}\text { Anthraquinone derived } \\
\text { emodin (a) }\end{array}$ \\
\hline
\end{tabular}

Senna obtusifolia L.

CN: Abejorra

Rheum spp.

Emodin (a)

$\mathrm{CN}$ : Rhubarb

Aloe spp.
CN: Aloe

$\mathrm{CN}$ : Aloe

Aloe emodin (a)

Essential oils:

b-ocimene, 1,8-cineole, a-pinene and b-pinene mainly (ad) emodin (a)

Vaccinium spp.

CN: Blueberry, mortiño,

Agráz, among others.
Anthocyanins (t), myricetin $(\mathrm{n})$, gallic acid $(\mathrm{u})$, stilbenoid resveratrol (s) and procyanidins (ai)
SARS-CoV, HSV-1/Inhibitory activity against viral replication in vitro by visually scoring of the [58] virus-induced cytopathogenic effect post-infection
SARS-CoV/Inhibits the end of the virus cycle infection

SARS-CoV, HCoV-OC43/inhibits by blocking viral entry by binding to the $S$ protein and interfering with the 3CLpro activity of the SARS-CoV and prevented the formation of the Nsp required for viral replication; Blocked the interaction between SARS-CoV S protein and ACE2, inhibited ion channel 3a and interrupted the release of new coronaviruses

\section{[59]}

[28]

[29]

[47]

\section{SARS-CoV, MERS-CoV/(t) inhibits the} production of $\mathrm{NO}$ and the secretion of TNF- $\alpha$ in macrophages induced by LPS-INF- $\gamma$ caused by protocatechic acid, also show ACE inhibitory activity; (n) inhibits the coronavirus helicase protein by affecting the ATPase activity in vitro; Gallic acid decreases the secretion of MCP-1, ICAM-1, and VCAM-1 in endothelial cells; (s) partially mitigates induced cell death and reduces infectious viral replication; (v) possibly blocks the entry of cells through endocytosis

Vitis vinifera $\mathrm{L}$.

CN: Red grape

Zingiber officinale Rosc.
CN: Ginger

[6]-gingerol (ak)

SARS-CoV-2/TMPRSS2 receptor blocking

The Renin-Angiotensin-Aldosterone System (RAAS) is a cascade of vasoactive peptides that regulate key processes in human physiology. SARS-CoV-1 and SARS-CoV-2 interfere with the RAAS by binding to the Angiotensin-Converting Enzyme 2 (ACE2) which serves as a receptor for both SARS viruses [66]. Overactivation of the RAAS by coronaviruses can contribute to the development of critical symptoms. Several common foods belonging to the families Alliaceae, Apiaceae, Brassicaceae, Cucurbitaceae, Rutaceae, Vitaceae, Zingiberaceae, among others have demonstrated the ability to regulate key RAAS processes $[38,60]$ (Table 3).

Various countries such as Ecuador are considered megadiverse because of the high number of plant species. Various species from megadiverse areas have shown great potential for the treatment of respiratory conditions but have not been tested against coronaviruses (Table 4) [66]. Further research is needed to assess the effect of these species against SARS-CoV-2. The pandemic impact of the 2002 SARS epidemic that began in Foshan, China [38,67], the high mortality rate and the subsequent re-emergence of the disease one year later [60] together with the economic problems caused in Asia encouraged research efforts focused on controlling coronaviruses infections by medicinal plants [68]. 
The aim of this review was to summarize the available literature on medicinal plants used against various types of coronaviruses, including SARS CoV-2 [67]. Special emphasis was placed on species located in Ecuador as one of the megadiverse countries.

Table 3. Studies based on food for human consumption ACEi activity () and inhibition of AII to AT1R binding activity (ATRi). Individual results are given (ACE-\%; ATR-\%), based on studies by Patten et al., (2012) y Patten et al., $(2016)[38,60]$.

\begin{tabular}{|c|c|}
\hline Family & Common Name of Plant with ACE and AT1R Inhibition Activities (\%, \%) \\
\hline Actinidiaceae & Gold kiwi $(-0.2 ; 20.5)$, green kiwi $(16.6 ; 2.5)$ \\
\hline Agaricaceae & Button mushroom $(12.5 ; 0.3)$ \\
\hline Alliaceae & $\begin{array}{l}\text { Chives }(23.2 ; 28.4) \text {, garlic }(6.8 ; 27.4) \text {, leek }(2.8 ; 42.7) \text {, onion }(-1.2 ; 34.2) \text {, shallot }(0.9 ; 11.5) \text {, red onion }(-4.0 ; 31.8) \text {, spring onion }(6.4 ; 53.3) \text {, } \\
\text { white onion }(-1.2 ; 18.8)\end{array}$ \\
\hline Amaranthaceae & Spinach $(-0.7 ; 29.6)$ \\
\hline Apiaceae & $\begin{array}{l}\text { Black carrot juice }(91.1 ; 31.0) \text {, carrot }(0.7 ; 5.0) \text {, coriander leaf }(37.4 ; 56.6) \text {, } \\
\text { coriander seed }(11.7 ; 16.4) \text {, fennel }(-2.1 ; 15.2) \text {, parsley }(8.2 ; 41.3)\end{array}$ \\
\hline Arecaceae & Coconut $(11.8 ;-18.0)$ \\
\hline Asparagaceae & Asparagus $(35.1 ; 27.7)$ \\
\hline Asteraceae & Radicchio $(56 ; 43.5)$, red coral lettuce $(31.5 ; 15.8)$, tarragon $(32.1 ; 30.7)$ \\
\hline Auricularaceae & Wood Ear mushroom $(13.1 ; 33.4)$ \\
\hline Betulaceae & Hazelnut $(-9.8 ; 25.1)$ \\
\hline Brassicaceae & $\begin{array}{l}\text { Bok choi }(7.1 ; 30.4) \text {, broccoli }(6.1 ; 0.2) \text {, brussel sprout }(10.3 ; 1.2) \text {, Chinese broccoli }(21.9 ; 38.7), \text { Chinese cabbage }(6.5 ; 28.8) \text {, choi sum }(21.8 ; 2.6) \text {, } \\
\text { red cabbage }(24.6 ; 6.0) \text {, savoy cabbage }(2.2 ; 52.1) \text {, watercress }(18.7 ; 27.9) \text {, yellow mustard seed }(5.2 ;-1.8)\end{array}$ \\
\hline Chenopodiacea & Silver beet $(-1.0 ; 31.7)$, rainbow silver beet $(-3.2 ; 10.2)$, beetroot $(0.8 ; 6.2)$ \\
\hline Combretaceae & Kakadu plum $(48.7 ; 0.0)$ \\
\hline Convolvulaceae & Red sweet potato $(8.6 ; 16.5)$, sweet potato $(4.9 ; 26.0)$ \\
\hline Cucurbitaceae & Choko $(5.2 ; 3.4)$, choko skin $(53.2 ; 14.0)$, cucumber $(14.6 ; 40.8)$, pumpkin $(3.3 ; 1.1)$, squash $(4.3 ; 46.0)$, zucchini $(16.0 ; 11.8)$ \\
\hline Ericaceae & Blueberry $(-0.1 ; 43.3)$ \\
\hline Fabaceae & Green bean $(10.7 ; 27.2)$, green pea $(-7.2 ; 9.3)$, lupin $(-15.4 ; 12.1)$, Parafield lupin $(-24.3 ; 7.6)$, peanut $(1.4 ;-16.7)$ \\
\hline Fagaceae & Chestnut $(61.7 ;-5.6)$ \\
\hline Juglandaceae & Pecan nut $(0 ; 7.8)$, walnut $(-10.9 ; 2.4)$ \\
\hline Lamiaceae & $\begin{array}{l}\text { Green basil }(37.9 ; 26.4) \text {, purple basil }(46.3 ; 11.0) \text {, Thai basil }(69.5 ; 36.5) \text {, oregano }(67.5 ; 55.7) \text {, rosemary }(91.0 ; 55.7) \text {, sage }(89.3 ; 68.2) \text {, thyme } \\
(87.4 ; 42.1)\end{array}$ \\
\hline Lauraceae & Avocado $(6.2 ; 43.4)$, bay leaf $(34.9 ; 37.3)$, cinnamon $(100.0 ; 54.4)$, Indian bay leaf $(28.7 ; 0.4)$ \\
\hline Lythraceae & Pomegranate flesh $(-6.2 ; 10.7)$ \\
\hline Marasmiaceae & Enoki mushroom $(4.8 ;-3.7)$, Shiitake mushroom $(26.4 ; 11.8)$ \\
\hline Meriplaceae & Maitake mushroom $(67.0 ; 32.1)$ \\
\hline Myrtaceae & Clove $(66.1 ; 30.8)$, cedar Bay cherry $(63.8 ; 2.1)$, riberry $(11.3 ;-12.1)$ \\
\hline Poaceae & Corn $(0 ; 27.8)$, lemongrass $(5.0 ; 7.2)$ \\
\hline Podacarpaceae & Illawarra plum $(100 ; 7.0)$ \\
\hline Polygonaceae & Rhubarb $(16.3 ; 8.5)$ \\
\hline Rosaceae & Quince $(12.3 ; 11.1)$, raspberry $(6.2 ; 6.2)$, strawberry $(20.3 ; 3.5)$, red delicious apple $(6.8 ; 1.5)$ \\
\hline Rubiaceae & Columbian dark coffee bean (63.416.0), Mocha coffee bean $(56.7 ; 21.5)$ \\
\hline Rutaceae & $\begin{array}{l}\text { Desert lemon }(6.1 ;-0.6) \text {, green finger lime }(11.5 ; 15.8) \text {, red finger lime }(-6.3 ; 13.7) \text {, green citrus }(14.8 ; 21.1) \text {, lemon skin }(12.4 ; 7.9) \text {, lime } \\
(-16.4 ; 6.2) \text {, lime skin }(47.1 ; 33.8) \text {, mandarin }(0.2 ; 3.6) \text {, navel oranges }(6.5 ;-3.9) \text {, orange skin }(46.1 ; 7.8) \text {, red citrus }(2.9 ; 40.1) \text {, red citrus skin } \\
(11.8 ; 17.4) \text {, ruby grapefruit }(6.6 ; 14.9) \text {, Valencia orange }(1.5 ; 5.4) \text {, yellow citrus }(5.1 ; 18.6) \text {, yellow citrus skin }(10.5 ; 7.3)\end{array}$ \\
\hline Saccharomycetaceae & Brewer's yeast $(31.8 ;-19.3)$ \\
\hline Santalum & Quandong $(40.6 ; 8.5)$ \\
\hline Solanaceae & Potato $(1.6 ; 16.6)$ \\
\hline Sterculiaceae & Cocoa bean $(81.2 ; 10.5)$ \\
\hline Theaceae & English breakfast black tea $(88.8 ; 27.1)$, green tea $(41.1 ; 12.4)$, Japanese green tea $(100 ; 41.6)$, Madura black tea $(100 ; 30.5)$ \\
\hline Pleurotaceae & Oyster mushroom $(35.9 ; 16.1)$, Honey Brown mushroom $(14.6 ; 8.6)$ \\
\hline Vitaceae & $\begin{array}{l}\text { Muscat grape }(59.0 ;-2.8) \text {, white grape seed }(100 ; 0.0) \text {, red grape skin }(92.7 ; 14.4) \text {, Chambourcin grape }(58.2 ; 10.6) \text {, Muscat Hamburg grape } \\
(73.5 ;-7.9) \text {, Cabinet Sauvignon grape }(72.3 ; 0.0) \text {, Sun Muscat grape }(59.0 ;-1.0) \text {, Concord grape }(49.3 ;-3.3),\end{array}$ \\
\hline Zingiberaceae & Cardamom $(7.4 ; 1.2)$, ginger $(9.9 ; 38.0)$, tumeric $(15.1 ;-1.4)$ \\
\hline
\end{tabular}


Table 4. Plant species with potential for the bioprospecting of secondary metabolites located in Ecuador.

\begin{tabular}{|c|c|c|c|c|c|}
\hline Family & Potential Species & Origin & Region & $\begin{array}{l}\text { Potential Anti-Sars } \\
\text { Effect }\end{array}$ & References \\
\hline Betulaceae & Birches (Betula spp.) & Introduced & Sierra region & $\begin{array}{l}\text { Anticoagulants and } \\
\text { antirheumatic }\end{array}$ & [69] \\
\hline Burseraceae & Palo santo (Bursera graveolens Triana and Planch) & Native & $\begin{array}{l}\text { Coast and Sierra } \\
\text { regions }\end{array}$ & $\begin{array}{l}\text { Anti-inflammatory } \\
\text { and antioxidant }\end{array}$ & [70] \\
\hline Ericaceae & Mortiño (Vaccinium floribundum Kunth) & Endemic & Sierra region & Antioxidant & [29] \\
\hline \multirow[b]{2}{*}{ Euphorbiaceae } & Croto de monte (Croton rivinifolius Kunth) & Endemic & Coast region & $\begin{array}{l}\text { Anticarcinogenic and } \\
\text { antiviral }\end{array}$ & [70] \\
\hline & Dog tongue (Euphorbia neriifolia L.) & Introduced & Coast región & $\begin{array}{l}\text { Antitussive, } \\
\text { antifungal and } \\
\text { antitumor }\end{array}$ & [69] \\
\hline \multirow{2}{*}{ Fabaceae } & Frijolillo (Cassia tora L.) & Native & Coast región & $\begin{array}{l}\text { Anticoagulants and } \\
\text { anti-inflammatory }\end{array}$ & [70] \\
\hline & White rain (Gliricidia brenningii Harms) & Native & Coast región & $\begin{array}{l}\text { Antiherpetic and } \\
\text { anticarcinogenic }\end{array}$ & [29] \\
\hline \multirow{2}{*}{ Orchidaceae } & Orchid (Dendrobium spp.) & Introduced & $\begin{array}{l}\text { Coast, Sierra y } \\
\text { Amazon regions }\end{array}$ & Antiviral & [71] \\
\hline & Guayaquil Orchid (Encyclia angustiloba Schltr) & Endemic & Coast región & Antiviral & [71] \\
\hline Polygonaceae & Bloodroot (Polygonum arenastrum Boreau) & Introduced & $\begin{array}{l}\text { Coast y Amazon } \\
\text { regions }\end{array}$ & Antiviral & [59] \\
\hline \multirow{4}{*}{ Rubiaceae } & Cascarilla (Cinchona pubescens Vahl) & Native & Sierra region & Febrifuge, antiviral & [72] \\
\hline & Cat's claw (Uncaria tomentosa D. C.) & Native & $\begin{array}{l}\text { Sierra and Amazon } \\
\text { regions }\end{array}$ & Anti-inflammatory & [72] \\
\hline & Colorado (Simira ecuadoriensis Standl) & Endemic & Coast region & $\begin{array}{l}\text { Febrifuge and } \\
\text { antiviral }\end{array}$ & [72] \\
\hline & Crucita (Rosenbergiodendron formosum Fagerl.) & Native & Coast region & $\begin{array}{l}\text { Febrifuge and } \\
\text { antiviral }\end{array}$ & [72] \\
\hline Scrophulariaceae & Escrofularia (Scrophularia spp.) & Introduced & Coast región & $\begin{array}{l}\text { Anti-inflammatory } \\
\text { and antimicrobial }\end{array}$ & [69] \\
\hline Urticaceae & Nettle (Urtica urens L.) & Introduced & Sierra region & Antiviral & [72] \\
\hline
\end{tabular}

\section{Methods}

\section{Literature Search}

The PubMed, NCBI, Elsevier databases were used for searching natural compounds and medicinal plants with pharmacological activity against the SARS, MERS or SARS$\mathrm{CoV}$ coronaviruses. Keywords like coronavirus; COVID-19; medicinal plants; active principle; natural compounds; inhibitor; SARS; MERS or SARS-CoV-2; Spike protein; RAAS; Angiotensin-Converting-Enzyme Inhibitors (ACEi); Angiotensin Receptor Blocker (ARB) were used to carry out the search. In addition, studies published since 2002 were reviewed, as this was the year in which SARS was reported for the first time [73]. The common name of the studied plants was determined with the help of an expert botanist, using the references "Plantas Útiles de Litoral Ecuatoriano de Flor María Valverde Vadillo" [74] and the "Enciclopedia de las Plantas Útiles del Ecuador", and the databases "Herbario Rapid Reference" (https:/ / plantidtools.fieldmuseum.org/es/rrc/5581) Date accessed: 19 April 2019 and "Trópicos" (https:/ /www.tropicos.org/home) Date accessed: 14 May 2019.

\section{Pathogenesis of SARS-CoV-2}

SARS-CoV-2 relies on its $S$ protein to attach to human cells having an ACE2 receptor. Studies have shown that SARS-CoV-2 has a higher ACE2 binding affinity than SARS-CoV, supporting an efficient cell entry [75]. The $S$ protein from SARS-CoV-2 consists of subunits $\mathrm{S} 1$ and S2. While S1 is important for the virus attachment to the ACE2 receptor, S2 allows the fusion of the virus and cell membranes followed by the internalization of the viral 
genetic material. Therefore, after attachment to the ACE2 receptor, the S protein needs to be primed at the S1-S2 site by cellular proteases such as the Transmembrane Serine protease 2 (TMPRSS2) [35]. Therefore, the virus is capable of infecting human cells containing both ACE2 receptors and proteases such as the TMPRSS2, including lungs, small intestine, heart and kidney cells, as well as the nose, nasopharynx and oral mucosa [35]. Once inside the cell, the viral genetic material undergoes replication, synthesis of the $S$ protein as well as other polyproteins. Figure 1 shows the infection process of SARS-CoV-2 in human cells.

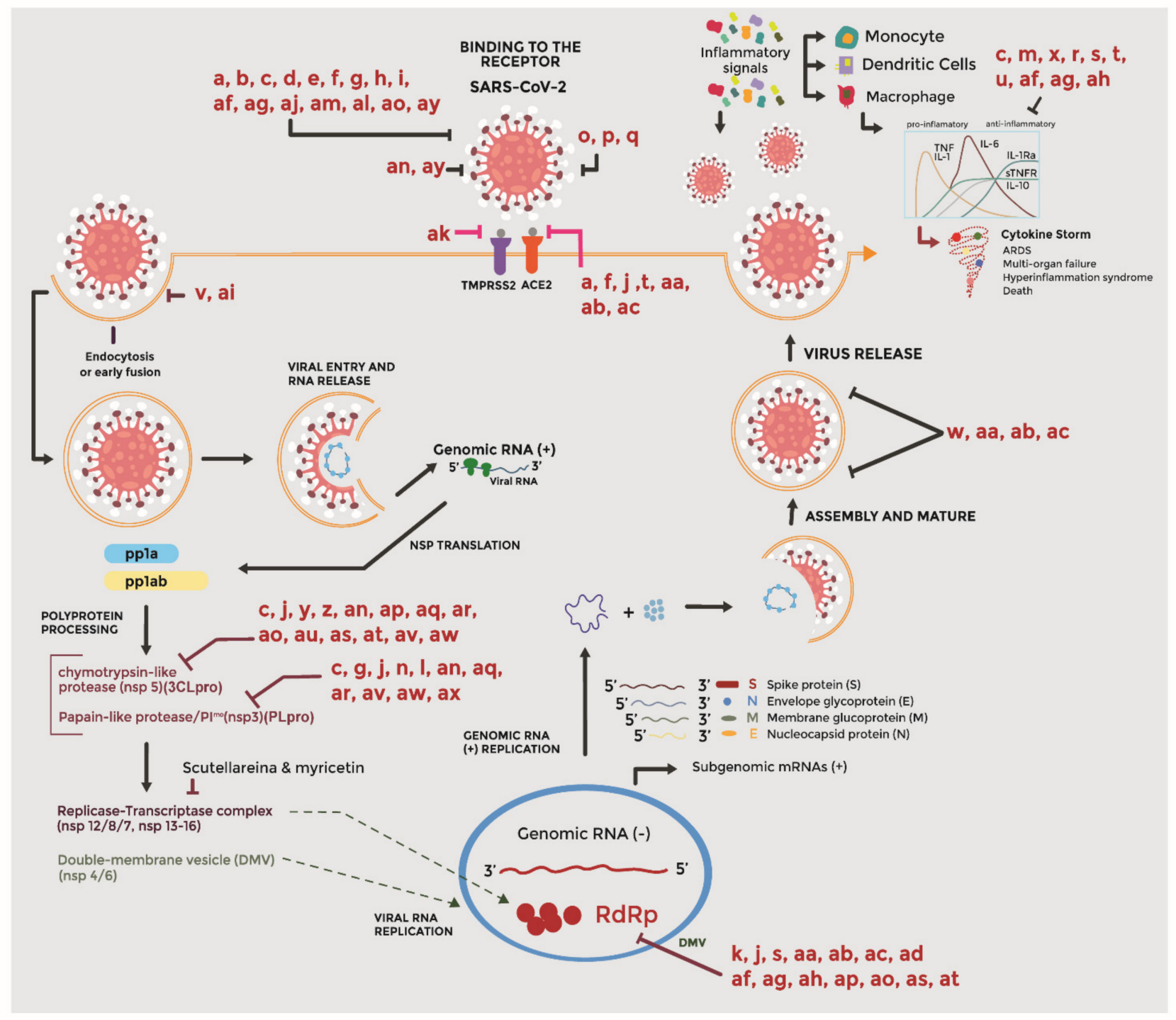

Figure 1. Various active principles and their mechanism of action. The infection cycle of SARS-CoV-2 in human cells. The SARS-CoV-2 spike (S) protein binds to ACE2 in host cells followed by priming of protein $\mathrm{S}$ by transmembrane protease serine 2 protease (TMPRSS2). Then, the virus produces the polyproteins pp1a and pp1ab, which are processed by viral proteases (3CLpro/Mpro, PLpro) to non-structural proteins (nsps), including RNA-dependent RNA polymerase (RdRp). Viral RdRp synthesizes a full-length complementary negative-strand RNA as a template for the production of the positive strand genome of the virus. Subgenomic mRNAs are then translated into structural proteins in the rough endoplasmic reticulum or in the cytosol. The viral genomic RNA is encapsulated by the nucleocapsid protein N and, finally, the virus is released by exocytosis. The blunt arrows indicate the possible targets of the active principles of medicinal plants. Irreversibly interference with viral docking receptors: Caphtharic acid (o), cichoric acid and echinacoside from Echinacea purpurea (p), vitamins D, C and Zn (q). Entry locks: Emodin (a), lectins (b), quercetin (c), catechin (d), naringenin (e), hesperetin (f), baicalin (g), epigallocatechin (h), gallocatechin gallate (i), prodelphinidin (af), gallocatechin (ag), saikosaponins derivatives of oleanane from Heteromorpha arborescens and Bupleurum spp. (aj), glycyrrhizine (al), Licorice (am), desmethoxyreserpine (ao), 
dihydrotanshinone I (ay). ACE2 receptor blocking: Emodin (a), hesperetin (f), kaempferol (j), anthocyanins (t), phenolic compounds: tannic acid (aa), 3-isotheaflavin-3-gallate (ab) and theaflavin-3,3'-digallate (ac) from Camellia sinensis. TMPRSS2 receptor blocking: [6]-gingerol (ak). Block the entry of cells through endocytosis: Butanol extract (v) and procyanidins (ai) from Cinnamomum verum. Inhibit 3CLpro: Quercetin (c), kaempferol (j), curcumin (y), sinigrin (z), eugenol (an), betulinic acid (ap), coumaroyltyramine (aq), cryptotanshinone (ar), desmethoxyreserpine (ao), Dihomo- $\gamma$ linolenic acid (au), lignan (as), sugiol (at), N-cis-feruloyltyramine (av), Tanshinone IIa (aw). Inhibit PLpro: Quercetin (c), baicalin (g), kaempferol (j), myricetin (n), scutellarein (1), eugenol (an), coumaroyltyramine (aq), cryptotanshinone (ar), Ncis-feruloyltyramine (av), Tanshinone IIa (aw), moupinamide (ax). Affinity with S protein: Eugenol (an), dihydrotanshinone I (ay). Viral replication: Aescin (k), kaempferol (j), resveratrol (s), prodelphinidin (af), gallocatechin (ag), epigallocatechin isomer (ah) from Pelargonium sidoides, essential oils: $\beta$-ocimene, 1,8 -cineole, $\alpha$-pinene and $\beta$-pinene (ad), phenolic compounds: tannic acid (aa), 3-isotheaflavin-3-gallate (ab) and theaflavin-3,3'-digallate (ac), betulinic acid (ap), desmethoxyreserpine (ao), lignan (as), sugiol (at). Affects the release or assembly of the virus: Phenolic compounds: tannic acid (aa), 3-isotheaflavin-3galalate (ab) and theaflavin-3,3'-digallate (ac), lectin agglutinin (w) from Hippeastrum striatum. TNF- $\beta$, IL- $1 \beta$ expressions: Quercetin (c), luteoloside (m), chlorogenic acid (x) geranylated flavonoids (tomebrin A, B, D and E) (r), resveratrol (s), anthocyanins (t), gallic acid (u), prodelphinidin (af), gallocatechin (ag), epigallocatechin isomer (ah).

The synthetized polyproteins are then processed by a 3C-like protease (3CLpro) also known as the main protease (MPro) and a PLpro to produce 16 nonstructural proteins (Nsp), including the Nsp13 helicase, responsible for the replication and transcription of the viral genome [18]. After cell entry and multiplication, the virus can cause inflammatory responses in the host attributed to an excessive release of cytokines. This cytokine storm has been associated with severe damage to the lungs, blood hypercoagulation, cardiac arrest and lymphocytopenia among other life-threatening conditions [76].

\subsection{The Renin-Angiotensin-Aldosterone System as Affected by SARS-CoV-2}

During the SARS-CoV-2 infection, the virus sequesters ACE2 causing the instability of the RAAS and contributing to various symptoms of COVID-19.

A stressed organism is usually more predisposed to infections by microorganisms [73]. Frequent or very strong episodes of stress caused by an overactivated RAAS include an excessive conversion of Angiotensin I (AI) into Angiotensin II (AII) by the ACE [77]. AII binds to the Angiotensin II Type I Receptor (AT1R), causing instability of blood pressure [78] as well as cardiovascular, renal [79] and prothrombotic issues [80]; myocardial dysfunction [81]; altered activity of the sympathetic nervous system [82]; and chronic hypertension in obese individuals [83]. AII is considered a cytokine with pro-inflammatory properties and the accumulation of this molecule can induce chemotaxis, contributing to a storm of cytokines [81,84]. To regulate the over-activated RAAS, ACE2 inactivates AII generating the harmless heptapeptide Angiotensin 1-7 (A1-7) with a powerful vasodilator function [85]. However, SARS-CoV-2 disrupts this mechanism after hijacking ACE2, causing the accumulation of AII and contributing to various symptoms of COVID-19 [66]. Therefore, the over-activation of RAAS should be prevented to reduce the severity of the infection [86]. Specific foods and plants that modulate the RAAS [60] can prevent the coronavirus entry or alleviate the COVID-19 symptoms. Figure 2 shows the effect of SARS-CoV-2 on the RAAS.

\subsection{Immune System Boosting Plants and Foods}

At present, different herbal plants are being subjected to studies on their ability to strengthen the immune system and cope up with the virus and some phytocompounds have already shown potential to mitigate the incidence of infection [87]. For instance, various plant polyphenols can initiate a cellular accumulation to then trigger signaling pathways and immune responses to infection. In addition, polyphenols are potent inhibitors of the COVID-19 protease (Mpro) [87]. 


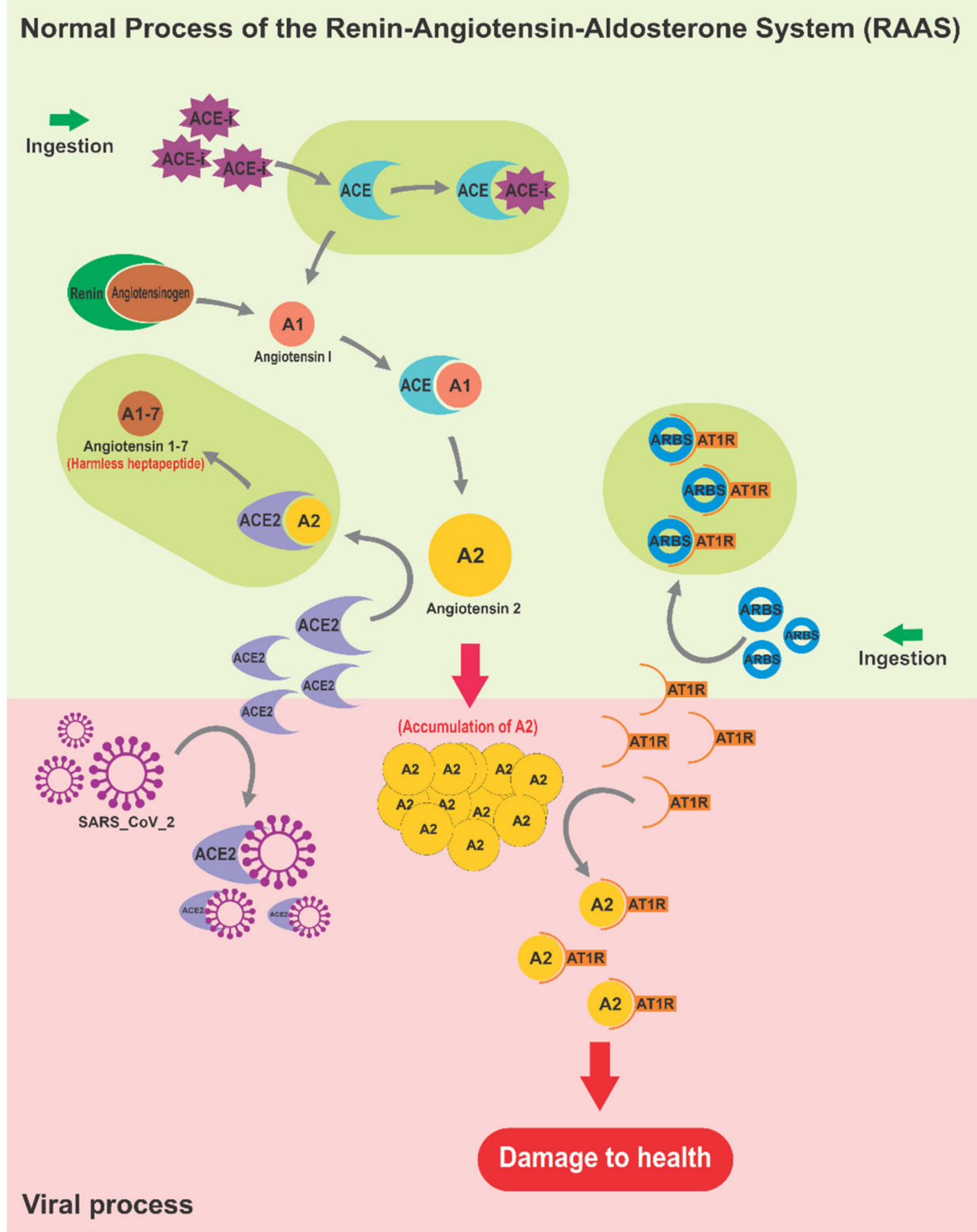

Figure 2. Mechanism of action of SARS-CoV-2 on the Renin-Angiotensin-Aldosterone System (RAAS) and its possible regulation by the Angiotensin converting enzyme inhibitors (ACEi), Angiotensin receptor blockers ARBs or Angiotensin converting enzyme (ACE2) that converts AI to A1-7 to restore the RAAS.

Natural polysaccharides and terpenoids are immunomodulatory as well as adaptogenic compounds and are also recognized for their antiviral, immunomodulatory, antitumor and anticoagulant bioactivities. Similarly, giloy herbs can stimulate IgG antibody response, macrophage activation, induction of cell-regulated immunity, and humoral immunity [87]. Moreover, several plant triterpenes such as dammaradienol, dammarenediol-II, hydroxyhopanone. dammarenolic acid, hydroxymarenone-I, ursonic acid, shoic acid, eichlerianic acid and hydroxyoleanonic lactone [87] play a vital role in the modulation of cellular metabolism [88].

Sulfated polysaccharides are a structurally multifaceted class of biomolecules with diverse physicochemical characteristics well recognized in the field of medicine and pharmaceutical sciences [29]. They have immunomodulatory properties and bioactivities [89]. 
Furthermore, they are selective inhibitors or suppressors of enveloped viruses, e.g., HSV, HIV, human cytomegalovirus, respiratory syncytial virus, and influenza [89].

The biomolecules hispidin, lepidine E, and folic acid from Citrus sp. inhibit the 3CL hydrolase enzyme known to counteract the host's innate immune response [90]. Similarly, Benzene 123 Triol from Nilavembu kudineer has shown immunomodulatory activity [91] while Exocarpium Citri grandis (Flavonoids and Naringin) stimulated the antiviral immune response and showed antitussive, expectorant and helped relieve pulmonary fibrosis [89]. Moreover, Allium sativum (Allicin) stimulated the activity of immune cells and inhibited the release of pro-inflammatory cytokines dependent on Necrosis Tumoral Factor alfa $(\mathrm{TNF} \alpha)$ as well as the migration of neutrophilic granulocytes, a crucial process during inflammation [46]. The plant species Acacia senegal, Laportea aestuans, and Citrus spp (Hesperidin) increased antioxidant defenses, modulated the activity of the immune system, and eliminated reactive oxygen species. In addition, Curcuma longa (Curcumin) also enhanced immunity [46].

Foods containing curcumin, allicin, papain, ginsenoside, mangoosteen, chloroquine, etc., have shown a direct effect on dendritic cells, natural killer cells (NK), lymphocytes and antibodies to protect the human body from foreign particles [89].

\section{Bioactive Compounds in the Mechanisms of the Virus-Host Interaction}

Table 2 shows the plant species with activity against various coronaviruses.

\subsection{Entry Inhibitors}

Many plant bioactive compounds typically prevent the entrance of the viral particle into the host cell [87]. SARS-CoV entry inhibitors are divided into two categories: the first consists of molecules that bind to the ACE2 and TMPRSS2 receptors while the second comprises compounds that bind to the virus and prevent interaction with the cell receptors and membrane fusion [92]. The molecule [6] gingerol from Zingiber officinale inhibits the growth of the coronavirus by blocking the cell's TMPRSS2 receptor [21].

The TCM's Jinchai consists of plant species such as Lonicera japonica and Bupleurum chinense among others, that prevent the coronavirus entry into cells and inhibit general viral replication as well as the specific 3CLpro-mediated replication [29]. One of the main active components of Jinchai is baicalin which inhibited antiviral activity with an Effective Concentration $\left(\mathrm{EC}_{50}\right.$ ) of $12-50 \mu \mathrm{g} / \mathrm{mL}$ in SARS-CoV-infected fetal rhesus monkey kidney cell line (fRHK4) and $\mathrm{EC}_{50}$ of $100 \mu \mathrm{g} / \mathrm{mL}$ in Vero-E6 cells [93].

Flavonoids stand out among the blockers of the ACE2 receptor, but they have also shown anti-replication activities. Similarly, compounds such as baicalin, epigallocatechin gallate, gallocatechin gallate, derivatives of kaempferol, myricetin, quercetin and scutellarein are other major constituents of TCM used to treat SARS by inhibiting the entry and replication of the virus [64].

The flavonoid hesperetin has the potential to inhibit ACE2 and block SARS-CoV-2 infection by binding to viralS protein, helicase, and protease sites of the ACE2 receptor [29].

Alternatively, computational analysis revealed that hesperidin, baicalin and kaempferol 3-O-rutinoside can block SARS-CoV-2 infection by weakening the adsorption of virus to cells $[19,46]$. Similarly, procyanidins and the butanol extract of Cinnamomi Cortex (bark of Cinnamomum verum) have shown antiviral effects at the RNA level, in addition to inhibiting SARS-CoV infection with an $\mathrm{IC}_{50}$ of $29.9 \pm 3.3 \mu \mathrm{M}$ (Tables 2 and 3) [30]. Additionally, cinnamon extract inhibited wild-type SARS-CoV infection in vitro with an $\mathrm{IC}_{50}$ of $43 \mu \mathrm{M}$ and blockage of the virus entry to the cell was suggested as the possible mechanism of action [32]. The polyphenol epigallocatechin gallate (EGCG) from Camellia sinensis (green tea) inhibited the spread of the bovine coronavirus and interfered with the viral adsorption to bovine kidney cells [94].

Among the virus-binding molecules, lectins have emerged as a new class of antivirals thanks to their ability to bind to the glycosylated molecules found on the surface of viruses such as the SARS-CoV spike glycoprotein [24]. One of the most potent molecules reported 
against SARS-CoV is the mannose-binding lectin isolated from leek (Allium porrum L.), with an $\mathrm{EC}_{50}$ of $0.45 \mu \mathrm{g} / \mathrm{mL}$ and a selectivity index $>222$ (Tables 2 and 3) [29]. Specific $\mathrm{N}$-acetylglucosamine lectins obtained from tobacco (Nicotiana tabacum L.) and stinging nettle (Urtica dioica $\mathrm{L}$.) were also active against SARS-CoV with selectivity indexes of $>77$ and $>59$, respectively [24]. Additionally, the mannose-specific lectin from Hippeastrum striatum (Lam.) has the potential to inhibit the final step of the virus infection cycle $[24,87]$. Similarly, triterpenoids such as glycyrrhizin from the licorice plant, Glycyrrhiza glabra L., have been reported to have in vitro anti-SARS effects with an $\mathrm{EC}_{50}$ of $300 \mu \mathrm{g} / \mathrm{mL}$ [51]. These natural compounds interfere with virus-host fusion steps through the envelope of the predominant heptad repeat 2 domains in viral envelopes [89].

Emodin is a natural anthraquinone derivative and an active ingredient of medicinal plants such as rhubarb (Genus Rheum) (Tables 2 and 3), Polygonum cuspidatum, Aloe vera, Senna obtusifolia [59] and Cassia tora L [28]. Emodin blocked SARS-CoV entry to host cells by binding to the $S$ proteins and interfering with the 3CLpro activity of the virus, thus preventing the formation of the Nsp required for replication [27]. In trials involving SARS$\mathrm{CoV}$ and OC43, emodin significantly blocked, in a dose-dependent manner, the interaction between SARS-CoV S protein and ACE2, inhibited the ion channel 3a and interrupted the release of new coronaviruses [22]. Similarly, terpenoids from medicinal plants exhibit general antiviral effects in vitro against SARS-CoV [29]. Oleanane-type saikosaponins found in medicinal plants such as Bupleurum spp. and Heteromorpha spp. prevented the entry of SARS-CoV into the cell [46].

\subsection{Protease Inhibitors}

Proteases are key players in the pathogenesis caused by SARS-CoV and SARS-CoV-2 as they are involved in the $S$ protein activation and viral replication. Therefore, protease inhibitors can aid the COVID-19 treatment. Because of the good binding affinity for Mpro and $S$ protein of eugenol and curcumin, these compounds can be considered promising anti-SARS-CoV agents [22,95]. Curcumin inhibited SARS-CoV 3CLpro with an $\mathrm{IC}_{50}$ value of $23.5 \mu \mathrm{M}[22,92]$. Similarly, various phenolic tea constituents, such as tannic acid, 3isotheaflavin-3-gallate and theaflavin-3,3-digallate (Tables 2 and 3) also inhibit SARS-CoV 3CLpro with $\mathrm{IC}_{50}$ values between 3,7 and $9.5 \mu \mathrm{M}$, respectively [37]. Similarly, a cell-based study showed that sinigrin significantly blocked the cleavage process of 3CLpro with an $\mathrm{IC}_{50}$ of $752 \mu \mathrm{M}$. Sinigrin is a glucosinolate found in some plants of the Brassicaceae family, such as Brussels sprouts, broccoli, and black mustard seeds [29] (Tables 2 and 3).

Scutellaria baicalensis polysaccharides, polyphenols and polyglycans can inhibit immune regulation and have shown antioxidant and antiviral activity [57]. The flavonoids scutellarein and baicalin from the same species inhibited SARS-CoV Nsp13 helicase [56], while myricetin reached an $\mathrm{IC}_{50}$ of $2.71 \mu \mathrm{M}$ against the virus [61]. These two compounds potently inhibited Nsp13 in vitro by affecting the ATPase activity of SARS-CoV [57].

\subsection{Replication Inhibitors}

Inhibitors of viral replication are amongst the key molecules to fight coronavirus diseases. The phenolic compounds from Melia azedarach (cinamomo or chinaberry tree) and Camellia sinensis (green tea) have shown antiviral activity due to the inhibition of RNA polymerase or the RNA-dependent proteases involved in the replication of the coronavirus RNA [29]. Additionally, tea extracts can also affect the virus assembly and release [96]. Similarly, the consecutive application of stilbene derivatives such as resveratrol at $62.5 \mu \mathrm{M}$ partially mitigated MERS-CoV-induced cell death and reduced the replication of infectious MERS-CoV by 10-fold [63]. Similarly, concentrations below $0.5 \mathrm{mg} / \mathrm{mL}$ of stilbene derivatives like resveratrol inhibited the replication of SARS-CoV in vitro [62]. These compounds are found in different plants, including the Vitis vinifera L. grape and berries of the genus Vaccinium (Tables 2 and 3) [30]. Compounds in berries have been suggested to block the virus entry to cells through endocytosis [97]. 
In general, natural flavonoids such as quercetin, catechin, naringenin and hesperetin are the most abundant polyphenols in the human diet, as they are found in fruits and vegetables as glycosides or acylglycosides [95]. Naringenin exhibited a partial inhibition of SARS-CoV-2 replication observed at $24 \mathrm{~h}$ post-infection (hpi) in cells upon Two-pore channel 2 (TPC2) silencing while stronger inhibition was observed at 48 and $72 \mathrm{hpi}$ [36].

The standardized extract of Pelargonium sidoides (EPS 7630), mainly containing polyphenolic compounds such as prodelphinidin, gallocatechin and its stereoisomer epigallocatechin $[53,98]$, is an approved treatment for acute bronchitis in Germany and other countries [53]. Concentrations up to $100 \mu \mathrm{g} / \mathrm{mL}$ of EPS 7630 interfered with the replication of human coronavirus as well as the seasonal influenza A virus Hemagglutinin Type 1 and Neuraminidase Type 1 (H1N1, H3N2), respiratory syncytial virus, parainfluenza virus and coxsackie virus [52] and inhibited the entry and replication of $229 \mathrm{E}$ with $\mathrm{EC}_{50}$ of $44.50 \pm 15.84 \mu \mathrm{g} / \mathrm{mL}[99]$.

The essential oils of Laurus nobilis and Salvia officinalis have also shown significant anti-replication activity against SARS-CoV with an Inhibitory Concentration $\left(\mathrm{IC}_{50}\right)$ value of $120 \mu \mathrm{g} / \mathrm{mL}$ [58]. Similarly, the essential oils from Thuja orientalis ( $\beta$-ocimene, 1,8-cineole, $\alpha$ pinene and $\beta$-pinene) also inhibited SARS-CoV replication [58] and the aescin isolated from the horse chestnut tree also inhibited SARS-CoV replication at non-toxic concentrations [22,100].

\subsection{Virucidal Activity}

The inactivation of the viral particles is another strategy to combat respiratory diseases. Echinacea purpurea extracts available as the commercial product Echinaforce ${ }^{\circledR}$ showed dosedependent inhibition of $229 \mathrm{E}$ infectivity in respiratory epithelial cells and this extract irreversibly inactivated the virus with an $\mathrm{IC}_{50}$ of $3.2 \mu \mathrm{g} / \mathrm{mL}$ [101] and $9 \pm 3 \mu \mathrm{g} / \mathrm{mL}$ in another study [76]. The multicomponent extract non-specifically and irreversibly interfered with viral docking receptors to block the infectivity of pathogens [102]. Similarly, inhibition for MERS-CoV was observed with $10 \mu \mathrm{g} / \mathrm{mL}$ of Echinaforce ${ }^{\circledR}$, reducing viral infectivity by $99.9 \%$ at $50 \mu \mathrm{g} / \mathrm{mL}$ [41]. Combining E. purpurea with vitamin D, vitamin C, and zinc has been suggested to reduce the risk of infection and death from SARS-CoV-2 [103]. A scientific review concluded that along with vitamin D, vitamin C and zinc, Echinacea extracts are pivotal in terms of prevention and treatment (shortening the duration and/or lessening the severity of symptoms) of common colds [104].

\subsection{Immunomodulatory Agents}

Generally, the viral loads observed in patients correlate with the severity of symptoms and mortality. The multisystem inflammatory syndrome, known as cytokine storm, occurring in many COVID-19 patients, is caused by an uncontrolled replication of the virus resulting in an over-activation of the immune system, including high levels of proinflammatory cytokines, i.e., interleukin-1 $\beta$ (IL-1 $\beta$ ) and TNF $\alpha$ [105]. The geranylated flavonoid tomentin E from Paulownia tomentosa inhibited SARS-CoV (PLpro) in a dosedependent manner with an $\mathrm{IC}_{50}$ between 5.0 and $14.4 \mu \mathrm{M}$ and reduced the concentration of the pro-inflammatory cytokines IL-1 $\beta$ and TNF $\alpha$ [51]. Similarly, one study observed that chlorogenic acid, luteoloside, quercetin, and other compounds in L. japonica, exhibited anti-inflammatory, antiviral, antibacterial, and antioxidant activity and enhanced immune response. It is known that one of the main possible anti-SARS mechanisms is decreasing the expression of inflammatory mediators such as the transforming growth factor-beta (TNF- $\beta$ ) and IL-1 $\beta$ [49].

Anthocyanins are found in red to violet fruits such as berries of the genus Vaccinium, blackberry, among others (Tables 2 and 3) [106]. Anthocyanin metabolites, such as the protocatechuic acid, were shown to weakly inhibit Nitric Oxide (NO) production and TNF$\alpha$ secretion in Lipopolysaccharide-Gamma interferon-induced macrophages (LPS-INF$\gamma$ ) [107]. Additionally, gallic acid decreased the secretion of the inflammatory mediators monocyte chemoattractant protein 1 (MCP-1), intercellular adhesion molecule 1 (ICAM1), and vascular cell adhesion molecule 1 (VCAM-1) in endothelial cells [83]. However, 
the anthocyanins concentrations used for the anti-inflammatory activity tests cannot be achieved physiologically [107]. Similarly, Echinacea has also been proposed as a suppressor of the immunoinflammatory cascades observed in COVID-19, thanks to the plant's ability to activate the anti-inflammatory cannabinoid-2 (CB2) receptors and peroxisome proliferatoractivated receptors gamma (PPAR $\gamma)$ [102].

\subsection{Regulators of RAAS}

Table 3 summarizes medicinal plants and purified bioactives with potential benefits against SARS-CoV-2, especially those that modulate the RAAS. For example, the ethanolic extract of Thymus vulgaris (thyme), among other plants has shown the inhibitory capacity of AT1R [34].

The onions tunic extract, rich in flavonols like quercetin, has been shown to be a competitive inhibitor of $\mathrm{ACE}$, comparable to pure quercetin ( $\mathrm{IC}_{50}: 0.36 \pm 0.04$ and $0.34 \pm 0.03 \mu \mathrm{g} / \mathrm{mL}$ respectively). This same extract further revealed competitive ACE inhibition with the substrate, N-[3-(2-furyl) acryloyl]-L-phenylalanylglycylglycine [26]. Agrawal and collegeus reported that quercetin can interfere with various stages of the coronavirus entry and replication cycle, such as PLpro, 3CLpro and nucleoside-triphosphatase (NTPase)/helicase, showing pleiotropic activities and lack of systemic toxicity [25]. Similarly, EGCG also inhibited ACE and blocked the AII binding to AT1R in vitro, showing the potential to control the symptoms of various diseases, especially those of a respiratory nature [108]. Further research is needed to assess the potential of EGCG for the treatment of symptoms caused by coronaviruses.

\subsection{Unknown Mechanisms of Action}

The lycorine purified from Lycoris spp. was identified as a promising anti-SARS-CoV bioactive compound with an $\mathrm{EC}_{50}$ value of $34.5 \pm 2.6 \mu \mathrm{g} / \mathrm{mL}$, by poorly understood mechanisms [50]. Flavonoids, benzofurans, stilbene, polyhydroxylated alkaloids, and kuwanons from Morus spp. have shown a large variety of pharmacological activities including antiviral activity but the mechanism is also unclear $[68,109]$. The same is through for the compounds from Ginkgo biloba (ginkgolide, terpenic lactones, flavonoids, polyphenols, oleic acid, among others) [110]. Therefore, further research is needed to resolve their antiviral mechanism(s) of action.

Recently, two naturally occurring alkaloid-derived compounds (homoharringtonine and emetine), effectively inhibited the SARS-CoV-2 in Vero E6 cells with an estimated EC50 of $2.55 \mu \mathrm{M}$ and $0.46 \mu \mathrm{M}$, respectively [111]. Similarly, emetine has been reported as an inhibitor of hCoV-OC43, hCoV-NL43, SARS-CoV MERS-CoV and MHV-A59 in vitro with EC50 at the low micromolar range. However, the study did not disclose the mechanisms by which both compounds induced anti-SARS-CoV-2 activity [112]. Emetine is a natural alkaloid isolated from Psychotria ipecacuanha and belongs to the methine class of alkaloids [113]. Similarly, homoharringtonine is a natural alkaloid derived from some species of the genus Cephalotaxus. This drug is a protein synthesis inhibitor and has been approved by the Food and Drug Administration (FDA) to treat chronic myeloid leukemia [112].

\section{Risks Associated with the Incorrect Use of Natural Products}

Although many of the plant species hold promise to reduce or mitigate COVID-19 symptoms, it is necessary to further validate their potential health benefits with clinical trials as well as to identify potential side effects. Despite the reported health benefits, high doses of ginkgo (Ginkgo biloba) [Table 2] can cause an increase in cerebral blood flow, and affect people with peptic ulcer and coagulation disorders [114,115].

Although no adverse effects have been reported in the consumption of ginger ([6]gingerol) (Table 2), irritation of the gastric mucosa has sometimes been mentioned. Similarly, turmeric should not be used in case of infections or inflammation of the hepato-bile duct or jaundice [115] and only the stem of rhubarb (Table 3) can be ingested as the leaves contain a large amount of oxalic acid that causes kidney stones [30]. Moreover, the exces- 
sive use of Aloe species (Table 2) can cause damage to the epithelium and the intestinal mucosa, hemorrhagic diarrhea, and kidney damage. Doses greater than $1 \mathrm{~g} /$ day are not recommended for pregnant women, women during menstruating periods or people suffering from kidney disease [115]. Consequently, medical observation is recommended for people who have never consumed any of the plants mentioned in this work. People must be properly informed of the contraindications before combining medicinal plants with any treatment against the symptoms of COVID-19 [116] in order to avoid a counterproductive effect.

\section{Conclusions}

Scientific evidence of medicinal plants and foods that can help to mitigate the symptoms of COVID-19 has been growing since the start of the pandemic. Therefore, it is important to promote the consumption of natural products under the supervision of experts in the medical, nutritional and pharmaceutical areas as well as encouraging the generation of scientific information that promotes the manufacture of plant-based products that help to better protect the people against the SARS-CoV2.

The identification of the antiviral mechanisms of natural agents acting in different stages of the viral life cycle offers hope for future antiviral therapies [16]. In addition, the elucidation of the mechanism of action of natural compounds against COVID-19 will contribute to discover promising anti-COVID-19 natural drugs [108]. However, it is important to emphasize that medicines for the treatment of COVID-19 should not be replaced by untested natural products. Good practices of bioprospecting of medicinal plants should be fostered, in order to increase the interests of the ancestral people from developing countries [116]. This will allow the promotion of the development of new natural products that mitigate the symptoms of this COVID-19 without leaving the vital specialized medical treatment [32].

Author Contributions: S.A.L.-C.: Review of databases, writing of article, creation and elaboration of the figures. J.N.-M.: Review of databases and writing of article. A.P.-A.: Review of databases and design and elaboration of the figures. L.P.: Article review and corrections. W.V.B.: Article review and corrections. P.M.: Article review and corrections. J.V.-P.: Review of databasesand, design and elaboration of the figures. F.L.-T.: Article review and writing. J.M.C.-C.: Article review, writing and elaboration of the figures. All authors have read and agreed to the published version of the manuscript.

Funding: This research is part of an international agreement between the Flemish Interuniversitary Council (VLIR-UOS) and the Ecuadorian Interuniversitary Network (VLIR-Network Ecuador).

Institutional Review Board Statement: Not applicable.

Informed Consent Statement: Not applicable.

Data Availability Statement: Not applicable.

Acknowledgments: This work was also supported by the Council of Flemish Universities of Belgium (VLIR) through.

Conflicts of Interest: The authors declare no conflict of interest.

\section{References}

1. Redeploying Plant Defences. Nat. Plants 2020, 6, 177. [CrossRef]

2. Petersen, E.; Koopmans, M.; Go, U.; Hamer, D.H.; Petrosillo, N.; Castelli, F.; Storgaard, M.; Khalili, S.A.; Simonsen, L. Comparing SARS-CoV-2 with SARS-CoV and Influenza Pandemics. Lancet Infect. Dis. 2020, 20, 238-244. [CrossRef]

3. Fani, M.; Teimoori, A.; Ghafari, S. Comparison of the COVID-2019 (SARS-CoV-2) Pathogenesis with SARS-CoV and MERS-CoV Infections. Future Virol. 2020, 15, 317-323. [CrossRef]

4. Caldaria, A.; Conforti, C.; Di-Meo, N.; Dianzani, C.; Mohammad, J.; Torello, L.; Zalaudek, I.; Giuffrida, R. COVID-19 and SARS: Differences and Similarities. Dermatol. Ther. 2020, e13395. [CrossRef]

5. Liu, Y.; Gayle, A.A.; Wilder-Smith, A.; Rocklöv, J. The Reproductive Number of COVID-19 is Higher Compared to SARS Coronavirus. J. Travel Med. 2020, 27, 1-4. [CrossRef] [PubMed] 
6. Perlman, S. Another Decade, Another Coronavirus. N. Engl. J. Med. 2020, 382, 760-762. [CrossRef] [PubMed]

7. Wen, C.-C.; Kuo, Y.-H.; Jan, J.-T.; Liang, P.-H.; Wang, S.-Y.; Liu, H.-G.; Lee, C.-K.; Chang, S.-T.; Kuo, C.-J.; Lee, S.-S.; et al. Specific Plant Terpenoids and Lignoids Possess Potent Antiviral Activities against Severe Acute Respiratory Syndrome Coronavirus. J. Med. Chem. 2007, 50, 4087-4095. [CrossRef] [PubMed]

8. Petrosillo, N.; Viceconte, G.; Ergonul, O.; Ippolito, G.; Petersen, E. COVID-19, SARS and MERS: Are They Closely Related? Clin. Microbiol. Infec. 2020, 26, 729-734. [CrossRef]

9. Lee, P.; Hu, Y.; Chen, P.; Huang, Y.; Hsueh, P. Are Children Less Susceptible to COVID-19? J. Microbiol. Immunol. Infect. 2020, 53, 371-372. [CrossRef]

10. Guerra, E. Recorte a la Educación Superior: Una Medida que Ahondará la Crisis—Opción S. Revista S. 2020. Available online: https:/ / opcions.ec/portal/2020/05/08/la-educacion-publica-y-el-recorte-presupuestario/ (accessed on 8 May 2020).

11. EMA. Treatments and Vaccines for COVID-19. European Medicines Agency. 2020. Available online: https://www.ema.europa.eu/ en/human-regulatory / overview / public-health-threats / coronavirus-disease-covid-19/treatments-vaccines-covid-19 (accessed on 8 November 2020).

12. ECDC. Vaccines and Treatment of COVID-19. European Centre for Disease Prevention and Control. 2020. Available online: https:/ / www.ecdc.europa.eu/en/covid-19/latest-evidence/treatment (accessed on 5 May 2021).

13. Mastroleo, I. Post-trial Obligations in the Declaration of Helsinki 2013: Classification, Reconstruction and Interpretation. Dev. World Bioeth. 2016, 16, 80-90. [CrossRef]

14. Dhama, K.; Karthik, K.; Khandia, R.; Munjal, A.; Tiwari, R.; Rana, R.; Khurana, S.; Khan, R.; Alagawany, M.; Farag, M. Medicinal and Therapeutic Potential of Herbs and Plant Metabolites/Extracts Countering Viral Pathogens-Current Knowledge and Future Prospects. Curr. Drug Metab. 2018, 19, 236-263. [CrossRef] [PubMed]

15. Akram, M.; Tahir, I.; Shah, S.; Mahmood, Z.; Altaf, A.; Ahmad, K.; Munir, N.; Daniyal, M.; Nasir, S.; Mehboob, H. Antiviral Potential of Medicinal Plants against HIV, HSV, Influenza, Hepatitis, and Coxsackievirus: A Systematic Review. Phytother. Res. 2018, 32, 811-822. [CrossRef]

16. Siddiqui, A.; Danciu, C.; Ashraf, S.; Moin, A.; Singh, R.; Alreshidi, M.; Patel, M.; Jahan, S.; Kumar, S.; Alkhinjar, M. Plants-Derived Biomolecules as Potent Antiviral Phytomedicines: New Insights on Ethnobotanical Evidences against Coronaviruses. Plants 2020, 9, 1244. [CrossRef] [PubMed]

17. Khare, P.; Sahu, U.; Pandey, S.; Samant, M. Current Approaches for Target-Specific Drug Discovery Using Natural Compounds against SARS-CoV-2 Infection. Virus Res. 2020, 290, 198169. [CrossRef]

18. Tahir, M.; Alqahtani, S.; Alamri, M.; Chen, L. Structural Basis of SARS-CoV-2 3CLpro and Anti-COVID-19 Drug Discovery from Medicinal Plants. J. Pharm. Anal. 2020, 1, 313-319. [CrossRef]

19. Zhang, D.; Wu, K.; Zhang, X.; Deng, S.; Peng, B. In Silico Screening of Chinese Herbal Medicines with the Potential to Directly Inhibit 2019 Novel Coronavirus. J. Integr. Med. 2020, 18, 152-158. [CrossRef]

20. Signer, J.; Jonsdottir, H.; Albrich, W.; Strasser, M.; Züst, R.; Ryter, S.; Ackermann, R.; Lenz, N.; Siegrist, D.; Suter, A. In Vitro Antiviral Activity of Echinaforce ${ }^{\circledR}$, an Echinacea purpurea Preparation, against Common Cold Coronavirus 229E and Highly Pathogenic MERS-CoV and SARS-CoV. Virol. J. 2020, 10, 2.

21. Tallei, T.; Tumilaar, S.; Niode, N.; Fatimawali, K.; Johnson, B.; Idroes, R.; Effendi, Y.; Sakib, S.; Emran, T. Potential of Plant Bioactive Compounds as SARS-CoV-2 Main Protease (Mpro) and Spike (S) Glycoprotein Inhibitors: A Molecular Docking Study. Scientifica 2020. [CrossRef] [PubMed]

22. Yang, Y.; Islam, M.; Wang, J.; Li, Y.; Chen, X. Traditional Chinese Medicine in the Treatment of Patients Infected with 2019-New Coronavirus (SARS-CoV-2): A Review and Perspective. Int. J. Biol. Sci. 2020, 16, 1708-1717. [CrossRef]

23. Lee, C. Griffithsin, a Highly Potent Broad-Spectrum Antiviral Lectin from Red Algae: From Discovery to Clinical Application. Mar. Drugs 2019, 17, 567. [CrossRef]

24. Keyaerts, E.; Vijgen, L.; Pannecouque, C.; Van-Damme, E.; Peumans, W.; Egberink, H.; Balzarini, J.; Van-Ranst, M. Plant Lectins are Potent Inhibitors of Coronaviruses by Interfering with Two Targets in the Viral Replication Cycle. Antivir. Res. 2007, 75, 179-187. [CrossRef] [PubMed]

25. Agrawal, P.; Agrawal, C.; Blunden, G. Quercetin: Antiviral Significance and Possible COVID-19 Integrative Considerations. Nat. Prod. Commun. 2020, 15, 1-10.

26. Olayeriju, O.; Crown, O.; Akinmoladun, A.; Kolawole, A.; Olaleye, M.; Akindahunsi, A. Onions tunic: A Flavonol Rich Competitive Inhibitor of Key Enzyme (Angiotensin-1 Converting Enzyme) Linked Hypertension. Int. J. Sci. Eng. Res. 2017, 8, 2229-5518.

27. Lin, C.; Tsai, F.; Tsai, C.; Lai, C.; Wan, L.; Ho, T.; Hsieh, C.; Chao, P. Anti-SARS Coronavirus 3C-Like Protease Effects of Isatis indigotica Root and Plant-Derived Phenolic Compounds. Antivir. Res. 2005, 68, 36-42. [CrossRef]

28. Hyun, S.; Lee, H.; Kang, S.; Chung, H.; Choi, J. Inhibitory Activities of Cassia tora and its Anthraquinone Constituents on Angiotensin-Converting Enzyme. Phyther. Res. 2009, 23, 178-184. [CrossRef] [PubMed]

29. Chinsembu, K. Coronaviruses and Nature's Pharmacy for the Relief of Coronavirus Disease 2019. Rev. Bras. Farmacogn. 2020, 30, 603-621. [CrossRef]

30. Zhuang, M.; Jiang, H.; Suzuki, Y.; Li, X.; Xiao, P.; Tanaka, T.; Ling, H.; Yang, B.; Saitoh, H.; Zhang, L. Procyanidins and Butanol Extract of Cinnamomi Cortex Inhibit SARS-CoV Infection. Antivir. Res. 2009, 82, 73-81. [CrossRef] 
31. Polansky, H.; Lori, G. Coronavirus Disease 2019 (COVID-19): First Indication of Efficacy of Gene-Eden-VIR/Novirin in SARSCoV-2 Infection. Int. J. Antimicrob. Agents 2020, 55, 105971. [CrossRef]

32. Temitope, A.; Eleojo, C.; Abiodun, I.; Ayokunnun, A.; Saheed, S. Phytotherapeutic Evidence against Coronaviruses and Prospects for COVID-19. Pharmacogn. J. 2020, 12, 1252-1267.

33. Shetty, R.; Ghosh, A.; Honavar, S.; Khamar, P.; Sethu, S. Therapeutic Opportunities to Manage COVID-19/SARS-CoV-2 Infection: Present and Future. Indian J. Ophthalmol. 2020, 68, 693-702.

34. Oladele, J.O.; Ajayi, E.I.; Oyeleke, O.M.; Oladele, O.T.; Olowookere, B.D.; Adeniyi, B.M.; Oyewole, O.I.; Oladiji, A.T. A Systematic Review on COVID-19 Pandemic with Special Emphasis on Curative Potentials of Nigeria Based Medicinal Plants. Heliyon 2020, 6, e04897. [CrossRef]

35. Li, H.; Liu, S.-M.; Yu, X.-H.; Tang, S.-L.; Tang, C.-K. Coronavirus Disease 2019 (COVID-19): Current Status and Future Perspectives. Int. J. Antimicrob. Agents 2020, 55, 105951. [CrossRef]

36. Clementi, N.; Scagnolari, C.; D'Amore, A.; Palombi, F.; Criscuolo, E.; Frasca, F.; Pierangeli, A.; Mancini, N.; Antonelli, G.; Clementi, M.; et al. Naringenin is a Powerful Inhibitor of SARS-CoV-2 Infection In vitro. Pharmacol. Res. 2021, 163, 105255. [CrossRef]

37. Bansal, S.; Choudhary, S.; Sharma, M.; Kumar, S.; Lohan, S.; Bhardwaj, V.; Syan, N.; Jyoti, S. Tea: A Native Nource of Antimicrobial Agents. Food Res. Int. 2013, 53, 568-584. [CrossRef]

38. Patten, G.S.; Abeywardena, M.Y.; Head, R.J.; Bennett, L.E. Processed Dietary Plants Demonstrate Broad Capacity for Angiotensin Converting Enzyme and Angiotensin II Receptor Binding Inhibition In Vitro. J. Funct. Foods 2012, 4, 851-863. [CrossRef]

39. Kim, H.; Shin, H.; Park, H.; Kim, Y.; Yun, Y.; Park, S.; Shin, H.; Kim, K. In Vitro Inhibition of Coronavirus Replications by the Traditionally Used Medicinal Herbal Extracts, Cimicifuga rhizoma, Meliae cortex, Coptidis rhizoma, and Phellodendron cortex. J. Clin. Virol. 2008, 41, 122-128. [CrossRef] [PubMed]

40. Schapowal, A. Use of Echinaforce to Prevent Coronavirus Infections. Switzerland. 2020. Available online: https://www.who.int/ emergencies / (accessed on 31 December 2019).

41. Engler, O.; Strasser, M.; Signer, J.; Schoop, R. Neutralizing Activity of Echinacea purpurea on Coronaviruses Including Highly Pathogenic Middle-East-Respiratory Syndrome Virus (MERS-CoV). Planta Med. Int. Open 2017, 4, 1-202. Available online: http:/ / www.thieme-connect.de/DOI/DOI?10.1055/s-0037-1608557 (accessed on 24 October 2017).

42. Banyeres, M. Herbario Virtual de Banyeres de Mariola y Alicante. 2010. Available online: http://herbariovirtualbanyeres. blogspot.com/2010/05/morus-alba-morera-morer.html (accessed on 26 May 2020).

43. Cinatl, J.; Morgenstern, B.; Bauer, G.; Chandra, P.; Rabenau, H.; Doerr, H. Glycyrrhizin, an Active Component of Liquorice Roots, and Replication of SARS-Associated Coronavirus. Lancet 2003, 361, 2045-2046. [CrossRef]

44. Baltina, L.; Zarubaev, V.; Baltina, L.; Orshanskaya, I.; Fairushina, A.; Kiselev, O.; Yunusov, M. Glycyrrhizic Acid Derivatives as Influenza A/H1N1 Virus Inhibitors. Bioorganic Med. Chem. Lett. 2015, 25, 1742-1746. [CrossRef]

45. Cheng, P.; Ng, L.; Chiang, L.; Lin, C. Antiviral Effects of Saikosaponins on Human Coronavirus 229E In vitro. Clin. Exp. Pharmacol. Physiol. 2006, 33, 612-616. [CrossRef]

46. Chen, F.; Chan, K.; Jiang, Y.; Kao, R.; Lu, H.; Fan, K.; Cheng, V.; Tsui, W.; Hung, I.; Lee, T. In Vitro Susceptibility of 10 Clinical Isolates of SARS Coronavirus to Selected Antiviral Compounds. J. Clin. Virol. 2004, 31, 69-75. [CrossRef] [PubMed]

47. Kumaki, Y.; Wandersee, M.; Smith, A.; Zhou, Y.; Simmons, G.; Nelson, N.; Bailey, K.; Vest, Z.; Li, J.; Chan, P. Inhibition of Severe Acute Respiratory Syndrome Coronavirus Replication in a Lethal SARS-CoV BALB/c Mouse Model by Stinging Nettle Lectin, Urtica dioica Agglutinin. Antivir. Res. 2011, 90, 22-32. [CrossRef] [PubMed]

48. Wang, Q.; Quan, Q.; Zhou, X.; Zhu, Y.; Lan, Y.; Li, S.; Yu, Y.; Cheng, Z. A Comparative Study of Lonicera japonica with Related Species: Morphological Characteristics, ITS Sequences and Active Compounds. Biochem. Syst. Ecol. 2014, 54, 198-207. [CrossRef] [PubMed]

49. Shang, X.; Pan, H.; Li, M.; Miao, X.; Ding, H. Lonicera japonica Thunb.: Ethnopharmacology, Phytochemistry and Pharmacology of an Important Traditional Chinese Medicine. J. Ethnopharmacol. 2011, 138, 1-21. [CrossRef]

50. Li, S.; Chen, C.; Zhang, H.; Guo, H.; Wang, H.; Wang, L.; Zhang, X.; Hua, S.; Yu, J.; Xiao, P. Identification of Natural Compounds with Antiviral Activities against SARS-Associated Aoronavirus. Antivir. Res. 2005, 67, 18-23. [CrossRef]

51. Cho, J.; Curtis-Long, M.; Lee, K.; Kim, D.; Ryu, H.; Yuk, H.; Park, K. Geranylated Flavonoids Displaying SARS-CoV Papain-Like Protease Inhibition from the Fruits of Paulownia tomentosa. Bioorganic Med. Chem. 2013, 21, 3051-3057. [CrossRef] [PubMed]

52. Michaelis, M.; Doerr, H.; Cinatl, J. Investigation of the Influence of EPs ${ }^{\circledR} 7630$, a Herbal Drug Preparation from Pelargonium sidoides, on Replication of a Broad Panel of Respiratory Viruses. Phytomedicine 2011, 18, 384-386. [CrossRef]

53. Theisen, L.L.; Muller, C.P. EPs ${ }^{\circledR} 7630$ (Umckaloabo ${ }^{\circledR}$ ), an Extract from Pelargonium sidoides Roots, Exerts Anti-influenza Virus Activity In Vitro and In Vivo. Antivir. Res. 2012, 94, 147-156. [CrossRef] [PubMed]

54. Moyo, M.; Van, J. Medicinal Properties and Conservation of Pelargonium sidoides DC. J. Ethnopharmacol. 2014, 152, 243-255. [CrossRef] [PubMed]

55. Lin, L.; Hsu, W.; Lin, C. Antiviral Natural Products and Herbal Medicines. J. Tradit. Complement. Med. 2014, 4, 24. [CrossRef]

56. Yu, M.S.; Lee, J.; Lee, J.M.; Kim, Y.; Chin, Y.W.; Jee, J.G.; Keum, Y.S.; Jeong, Y.J. Identification of Myricetin and Scutellarein as Novel Chemical Inhibitors of the SARS Coronavirus Helicase, nsP13. Bioorg. Med. Chem. Lett. 2012, 22, 4049-4054. [CrossRef]

57. Zhao, T.; Tang, H.; Xie, L.; Zheng, Y.; Ma, Z.; Sun, Q.; Li, X. Scutellaria baicalensis Georgi. (Lamiaceae): A Review of its Traditional Uses, Botany, Phytochemistry, Pharmacology and Toxicology. J. Pharm. Pharmacol. 2019, 71, 1353-1369. [CrossRef] [PubMed] 
58. Loizzo, M.; Saab, A.; Tundis, R.; Statti, G.; Menichimi, F.; Lampronti, D.; Gambari, R.; Cinatl, J.; Doerr, H. Phytochemical Analysis and In Vitro Antiviral Activities of the Essential Oils of Seven Lebanon Species. Chem. Biodivers. 2008, 5, 461-470. [CrossRef] [PubMed]

59. Dong, X.; Fu, J.; Yin, X.; Cao, S.; Li, X.; Lin, L.; Ni, J. Emodin: A Review of its Pharmacology, Toxicity and Pharmacokinetics. Phytother. Res. 2016, 30, 1207-1218. [CrossRef]

60. Patten, G.S.; Abeywardena, M.Y.; Bennett, L.E. Inhibition of Angiotensin Converting Enzyme, Angiotensin II Receptor Blocking, and Blood Pressure Lowering Bioactivity across Plant Families. Crit. Rev. Food Sci. Nutr. 2016, 56, 181-214. [CrossRef] [PubMed]

61. Semwal, D.; Semwal, R.; Combrinck, S.; Viljoen, A. Myricetin: A Dietary Molecule with Diverse Biological Activities. Nutrients 2016, 8, 90. [CrossRef] [PubMed]

62. Li, Y.; Li, Z.; Zhao, W.; Wen, R.; Meng, Q.; Zeng, Y. Synthesis of Stilbene Derivatives with Inhibition of SARS Coronavirus Replication. Eur. J. Med. Chem. 2006, 41, 1084-1089. [CrossRef] [PubMed]

63. Lin, S.; Ho, C.; Chuo, W.; Li, S.; Wang, T.; Lin, C. Effective Inhibition of MERS-CoV Infection by Resveratrol. BMC Infect. Dis. 2017, 17, 144. [CrossRef]

64. Maurya, V.K.; Kumar, S.; Bhatt, M.L.; Saxena, S.K. Therapeutic Development and Drugs for the Treatment of COVID-19. In Coronavirus Disease 2019 (COVID-19); Nature Publishing Group: Berlin, Germany, 2020; pp. 109-126.

65. Palit, P.; Chattopadhyay, D.; Thomas, S.; Kundu, A.; Kim, H.; Rezaei, N. Phytopharmaceuticals Mediated Furin and TMPRSS2 Receptor Blocking: Can It Be a Potential Therapeutic Option for Covid-19? Phytomedicine 2020, 85, 153396. [CrossRef]

66. Vaduganathan, M.; Vardeny, O.; Michel, T.; McMurray, J.J.; Pfeffer, M.A. Solomon SD. Renin-Angiotensin-Aldosterone System Inhibitors in Patients with Covid-19. N. Engl. J. Med. 2020, 382, 1653-1659. [CrossRef]

67. Christy, M.; Uekusa, Y.; Gerwick, L.; Gerwick, W. Natural Products with Potential to Treat RNA Virus Pathogens Including SARS-CoV-2. J. Nat. Prod. 2021, 84, 161-182. [CrossRef] [PubMed]

68. Manzano, P.; Peñarreta, J.; Chóez, I.; Barragán, A.; Orellana, A.; Rastrelli, L. Potential Bioactive Compounds of Medicinal Plants against New Coronavirus (SARS-CoV-2): A Review. Bionatura 2020. [CrossRef]

69. Balslev, H.; Navarrete, H.; Torre, L.; Macía, M. Enciclopedia de Plantas Útiles del Ecuador; Herbario QCA de la Escuela de Ciencias Biológicas de la Pontificia, Universidad Católica del Ecuador: Quito, Ecuador, 2008; pp. 1-323.

70. León, S.; Valencia, R.; Pitman, N.; Endara, L.; Ulloa, H.; Navarrete, C. Libro Rojo de las Plantas Endémicas del Ecuador, 2nd ed.; Pontifica Universidad Católica del Ecuador: Quito, Ecuador, 2011; pp. 1-440.

71. Sut, S.; Maggi, F.; Dall'Acqua, S. Bioactive Secondary Metabolites from Orchids (Orchidaceae). Chem. Biodivers. 2017, 14, e1700172. [CrossRef] [PubMed]

72. Naranjo, P.; Escaleras, R. La Medicina Tradicional en el Ecuador: Memorias de las Primeras Jornadas Ecuatorianas de Etnomedicina Andina; Universidad Andina Simón Bolívar: Quito, Ecuador, 2002; pp. 1-192.

73. Selmi, C.; Ansari, A.; Invernizzi, P.; Podda, M.; Gershwin, E. The Search for a Practical Approach to Emerging Diseases: The Case of Severe Acute Respiratory Syndrome (SARS). Dev. Immunol. 2002, 9, 113-117. [CrossRef]

74. Zhong, N. Management and Prevention of SARS in China. R. Soc. 2004, 359, 1115-1116. [CrossRef] [PubMed]

75. Cheng, V.; Lau, S.; Woo, P.; Yuen, K. Severe Acute Respiratory Syndrome Coronavirus as an Agent of Emerging and Reemerging Infection. Clin. Microbiol. Rev. 2007, 20, 660-694. [CrossRef]

76. Ruiz, M.; Ruperez, M.; Lorenzo, O.; Esteban, V.; Blanco, J.; Mezzano, S.; Egido, J. Angiotensin II Regulates the Synthesis of Proinflammatory Cytokines and Chemokines in the Kidney. Kidney Int. Suppl. 2002, 62, 12-22. [CrossRef]

77. Carlson, S.H.; Wyss, J.M. Mechanisms Underlying Hypertension and Obesity. Hypertension 2011, 57, 375-376. [CrossRef]

78. Valverde, F.D.M. Plantas Utiles del Litoral Ecuatoriano; Fundación Ecuatoriana de Estudios Ecológicos: Quito, Ecuador, 1998.

79. Shang, J.; Wan, Y.; Luo, C.; Ye, G.; Geng, Q.; Auerbach, A.; Li, F. Cell Entry Mechanisms of SARS-CoV-2. Proc. Natl. Acad. Sci. USA 2020, 117, 11727-11734. [CrossRef]

80. Sawalha, A.; Zhao, M.; Coit, P.; Lu, Q. Epigenetic Dysregulation of ACE2 and Interferon-regulated Genes Might Suggest Increased COVID-19 Susceptibility and Severity in Lupus Patients. Clin. Immunol. 2020, 215, 108410. [CrossRef]

81. Remkova, A.; Remko, M. The Renin-Angiotensin-Aldosterone System and Prothrombotic State in Arterial Hypertension. Salud Cienc. 2011, 18, 220-224.

82. Ayada, C.; Toru, Ü.; Korkut, Y. The Relationship of Stress and Blood Pressure Effectors. Hippokratia 2015, 19, 99. [PubMed]

83. Gurwitz, D. Angiotensin Receptor Blockers as Tentative SARS-CoV-2 Therapeutics. Drug Dev. Res. 2020, 81, 537-540. [CrossRef] [PubMed]

84. Arnold, A.C.; Sakima, A.; Kasper, S.O.; Vinsant, S.; Garcia, M.A.; Diz, D.I. The Brain Renin-Angiotensin System and Cardiovascular Responses to Stress: Insights from Transgenic Rats with Low Brain Angiotensinogen. J. Appl. Physiol. 2012, 113, 1929-1936. [CrossRef]

85. Guo, F.; Chen, X.L.; Wang, F.; Liang, X.; Sun, Y.X.; Wang, Y.J. Role of Angiotensin II Type 1 Receptor in Angiotensin II-Induced Cytokine Production in Macrophages. J. Interferon Cytokine Res. 2011, 31, 351-361. [CrossRef]

86. Engeli, S.; Schling, P.; Gorzelniak, K.; Boschmann, M.; Janke, J.; Ailhaud, G.; Teboul, M.; Massiéra, F.; Sharma, A. The AdiposeTissue Renin-Angiotensin-Aldosterone System: Role in the Metabolic Syndrome? Int. J. Biochem. Cell Biol. 2003, 35, 807-825. [CrossRef]

87. Khanna, K.; Kohli, S.; Kaur, R.; Bhardwaj, A.; Bhardwaj, V.; Ohri, P.; Sharma, A.; Ahmad, A.; Bhardwaj, R.; Ahmad, P. Herbal Immune-Boosters: Substantial Warriors of Pandemic Covid-19 Battle. Phytomedicine 2021, 85, 153361. [CrossRef] 
88. Malinowska, M.; Sikora, E.; Ogonowski, J. Production of Triterpenoids with Cell and Tissue Cultures. Acta. Biochim. Pol. 2013, 60, 731-735. [CrossRef]

89. Teissier, E.; Penin, F.; Pécheur, E. Targeting Cell Entry of Enveloped Viruses as an Antiviral Strategy. Molecules 2011, 16, 221-250. [CrossRef]

90. Fedoung, E.F.; Biwole, A.B.; Biyegue, C.F.N.; Tounkam, M.N.; Ntonga, P.A.; Nguiamba, V.P.; Essono, D.M.; Funwi, P.F.; Tonga C.; Nguenang, G.M.; et al. A Review of Cameroonian Medicinal Plants with Potentials for the Management of the COVID-19 Pandemic. Adv. Tradit. Med. 2021, 1-26. [CrossRef]

91. Walter, T.; Justinraj, S.; Justinraj, C.; Nandini, V. Effect of Nilavembu Kudineer in the Prevention and Management of COVID-19 by Inhibiting ACE2 Receptor. Siddha Pap. 2020. Available online: www.siddhapapers.org (accessed on 21 December 2020).

92. Wu, C.; Liu, Y.; Yang, Y.; Zhang, P.; Zhong, W.; Wang, Y.; Wang, Q.; Xu, Y.; Li, M.; Li, X. Analysis of Therapeutic Targets for SARS-CoV-2 and Discovery of Potential Drugs by Computational Methods. Acta Pharm. Sin. B 2020, 10, 766-788. [CrossRef]

93. Liu, H.; Ye, F.; Sun, Q.; Liang, H.; Li, C.; Li, S.; Lu, R.; Huang, B.; Tan, W.; Lai, L. Scutellaria baicalensis Extract and Baicalein Inhibit Replication of SARS-CoV-2 and its 3C-like Protease In Vitro. J. Enzym. Inhib. Med. Chem. 2021, 36, 497-503. [CrossRef]

94. Maiti, S.; Banerjee, A. Epigallocatechin Gallate and Theaflavin Gallate Interaction in SARS-CoV-2 Spike-protein Central Channel with Reference to the Hydroxychloroquine Interaction: Bioinformatics and Molecular Docking Study. Drug Dev. Res. 2021, 82, 86-96. [CrossRef]

95. Ngwa, W.; Kumar, R.; Thompson, D.; Lyerly, W.; Moore, R.; Reid, T.E.; Lowe, H.; Toyang, N. Potential of Flavonoid-Inspired Phytomedicines against COVID-19. Molecules 2020, 25, 2707. [CrossRef]

96. Chen, C.; Lin, C.; Huang, K.; Chen, W.; Hsieh, H.; Liang, P.; Hsu, J. Inhibition of SARS-CoV 3C-Like Protease Activity by Theaflavin-3,3'- Digallate (TF3). Evid. Based Complementary Altern. Med. 2005, 2, 209-215. [CrossRef] [PubMed]

97. Musarra, M.; Pennisi, R.; Ben, I.; Mandalari, G.; Sciortino, M.T. Antiviral Activity Exerted by Natural Products against Human Viruses. Viruses 2021, 13, 828. [CrossRef] [PubMed]

98. Schötz, K.; Nöldner, M. Mass Spectroscopic Characterisation of Oligomeric Proanthocyanidins Derived from an Extract of Pelargonium sidoides Roots (EPs ${ }^{\circledR}$ 7630) and Pharmacological Screening in CNS Models. Phytomedicine 2007, 14, 32-39. [CrossRef] [PubMed]

99. Verma, S.; Twilley, D.; Esmear, T.; Oosthuizen, C.; Reid, A.M.; Nel, M.; Lall, N. Anti-SARS-CoV Natural Products with the Potential to Inhibit SARS-CoV-2 (COVID-19). Front. Pharmacol. 2020, 11, 1514. [CrossRef]

100. Orhan, I.E.; Senol, F.S. Natural Products as Potential Leads Against Coronaviruses: Could They be Encouraging Structural Models Against SARS-CoV-2? Nat. Prod. Bioprospecting 2020, 10, 171-186. [CrossRef]

101. Signer, J.; Jonsdottir, H.R.; Albrich, W.C.; Strasser, M.; Züst, R.; Ryter, S.; Ackermann, R.; Lenz, N.; Siegrist, D.; Suter, A. In Vitro Virucidal Activity of Echinaforce ${ }^{\circledR}$, an Echinacea purpurea Preparation, against Coronaviruses, Including Common Cold Coronavirus 229E and SARS-CoV-2. Virol. J. 2020, 17, 136. [CrossRef]

102. Meeran, M.N.; Javed, H.; Sharma, C.; Goyal, S.N.; Kumar, S.; Jha, N.K.; Ojha, S. Can Echinacea be a Potential Candidate to Target Immunity, Inflammation, and Infection-The Trinity of Coronavirus Disease 2019. Heliyon 2021, 7, e05990. [CrossRef]

103. Grant, W.; Lahore, H.; McDonnell, S.; Baggerly, C.; French, C.; Aliano, J.; Bhattoa, H. Evidence that Vitamin D Supplementation Could Reduce Risk of Influenza and COVID-19 Infections and Deaths. Nutrients 2020, 12, 988. [CrossRef] [PubMed]

104. Rondanelli, M.; Miccono, A.; Lamburghini, S.; Avanzato, I.; Riva, A.; Allegrini, P.; Faliva, M.; Peroni, G.; Nichetti, M.; Perna, S Self-Care for Common Colds: The Pivotal Role of Vitamin D, Vitamin C, Zinc, and Echinacea in Three Main Immune Interactive Clusters (Physical Barriers, Innate and Adaptive Immunity) Involved During an Episode of Common Colds-Practical Advice on Dosages. Evid. Based Complementary Altern. Med. 2018, 2018, 5813095. [CrossRef] [PubMed]

105. Wong, S.S.; Yuen, K.Y. The Management of Coronavirus Infections with Particular Reference to SARS. J. Antimicrob. Chemother. 2008, 62, 437-441. [CrossRef] [PubMed]

106. Llivisaca, S.; Manzano, P.; Ruales, J.; Flores, J.; Mendoza, J.; Peralta, E.; Cevallos-Cevallos, J.M. Chemical, Antimicrobial, and Molecular Characterization of Mortiño (Vaccinium floribundum Kunth) Fruits and Leaves. Food Sci. Nutr. 2018, 6, 934-942. [CrossRef]

107. Hidalgo, M.; Martin, S.; Recio, I.; Sanchez, C.; De Pascual, B.; Rimbach, G.; De Pascual, S. Potential Anti-inflammatory, Antiadhesive, Anti/Estrogenic, and Angiotensin-Converting Enzyme Inhibitory Activities of Anthocyanins and their Gut Metabolites. Genes Nutr. 2012, 7, 295-306. [CrossRef] [PubMed]

108. Muchtaridi, M.; Fauzi, M.; Khairul Ikram, N.K.; Mohd Gazzali, A.; Wahab, H.A. Natural Flavonoids as Potential AngiotensinConverting Enzyme 2 Inhibitors for Anti-SARS-CoV-2. Molecules 2020, 25, 3980. [CrossRef]

109. Thabti, I.; Albert, Q.; Philippot, S.; Dupire, F.; Westerhuis, B.; Fontanay, S.; Risler, A.; Kassab, T.; Elfalleh, W.; Aferchichi, A.; et al. Advances on Antiviral Activity of Morus spp. Plant Extracts: Human Coronavirus and Virus-related Respiratory Tract Infections in the Spotlight. Molecules 2020, 25, 1876. [CrossRef]

110. Xian, Y.; Zhang, J.; Bian, Z.; Zhou, H.; Zhang, Z.; Lin, Z.; Xu, H. Bioactive Natural Compounds against Human Coronaviruses: A Review and Perspective. Acta Pharm. Sin. B 2020, 10, 1163-1174. [CrossRef] [PubMed]

111. Choy, K.; Wong, A.; Kaewpreedee, P.; Sia, S.; Chen, D.; Hui, K.; Chu, D.; Chan, M.; Cheung, P.; Huang, X. Remdesivir, Lopinavir, Emetine, and Homoharringtonine Inhibit SARS-CoV-2 Replication In vitro. Antivir. Res. 2020, 178, 104786. [CrossRef] [PubMed]

112. Hassan, S. Shedding Light on the Effect of Natural Anti-Herpesvirus Alkaloids on SARS-CoV-2: A Treatment Option for COVID-19. Viruses 2020, 12, 476. [CrossRef] [PubMed] 
113. Valadão, A.L.; Abreu, C.M.; Días, J.Z.; Arantes, P.; Verli, H.; Tanuri, A.; De Aguiar, R.S. Natural Plant Alkaloid (Emetine) Inhibits HIV-1 Replication by Interfering with Reverse Transcriptase Activity. Molecules 2015, 20, 11474-11489. [CrossRef]

114. Bian, Y.; An, G.J.; Kim, K.; Ngo, T.; Shin, S.; Bae, O.N.; Lim, K.M.; Chung, J.H. Ginsenoside Rg3, a Component of Ginseng, Induces Pro-thrombotic Activity of Erythrocytes Via Hemolysis-associated Phosphatidylserine Exposure. Food Chem. Toxicol. 2019, 131, 110553. [CrossRef] [PubMed]

115. Gafner, S. Herbal Drugs and Phytopharmaceuticals, 3rd ed.; American Chemical Society: London, UK, $2004 ;$ pp. $1774-1775$.

116. Efferth, T.; Banerjee, M.; Paul, N.; Abdelfatah, S.; Arend, J.; Elhassan, G.; Hamdoun, S.; Hamm, R.; Hong, C.; Kadioglu, O. Biopiracy of Natural Products and Good Bioprospecting Practice. Phytomedicine 2016, 23, 166-173. [CrossRef] 